TA7

W $34 \mathrm{~m}$

no. GL-92-17

c. 3

of Engineers

\title{
A CASE STUDY: DAMAGE TO THE METROPOLITAN OAKLAND INTERNATIONAL AIRPORT CAUSED BY THE LOMA PRIETA EARTHQUAKE
}

\author{
by \\ Barney A. Vallerga \\ B. A. Vallerga, Inc. \\ Oakland, California 94612 \\ and \\ William P. Grogan \\ Geotechnical Laboratory \\ DEPARTMENT OF THE ARMY \\ Waterways Experiment Station, Corps of Engineers \\ 3909 Halls Ferry Road, Vicksburg, Mississippi 39180-6199 \\ US-CE-C property of the \\ UNITED STATES GOVERNMENT

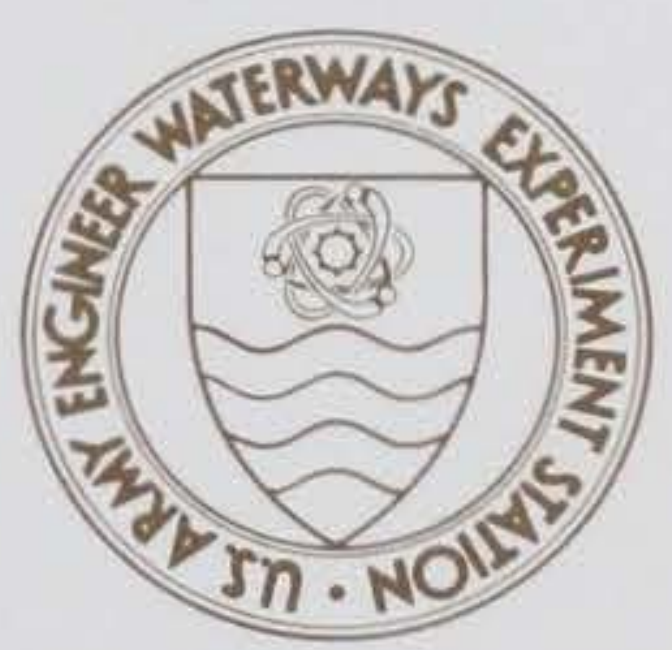 \\ July 1992 \\ Final Report
}

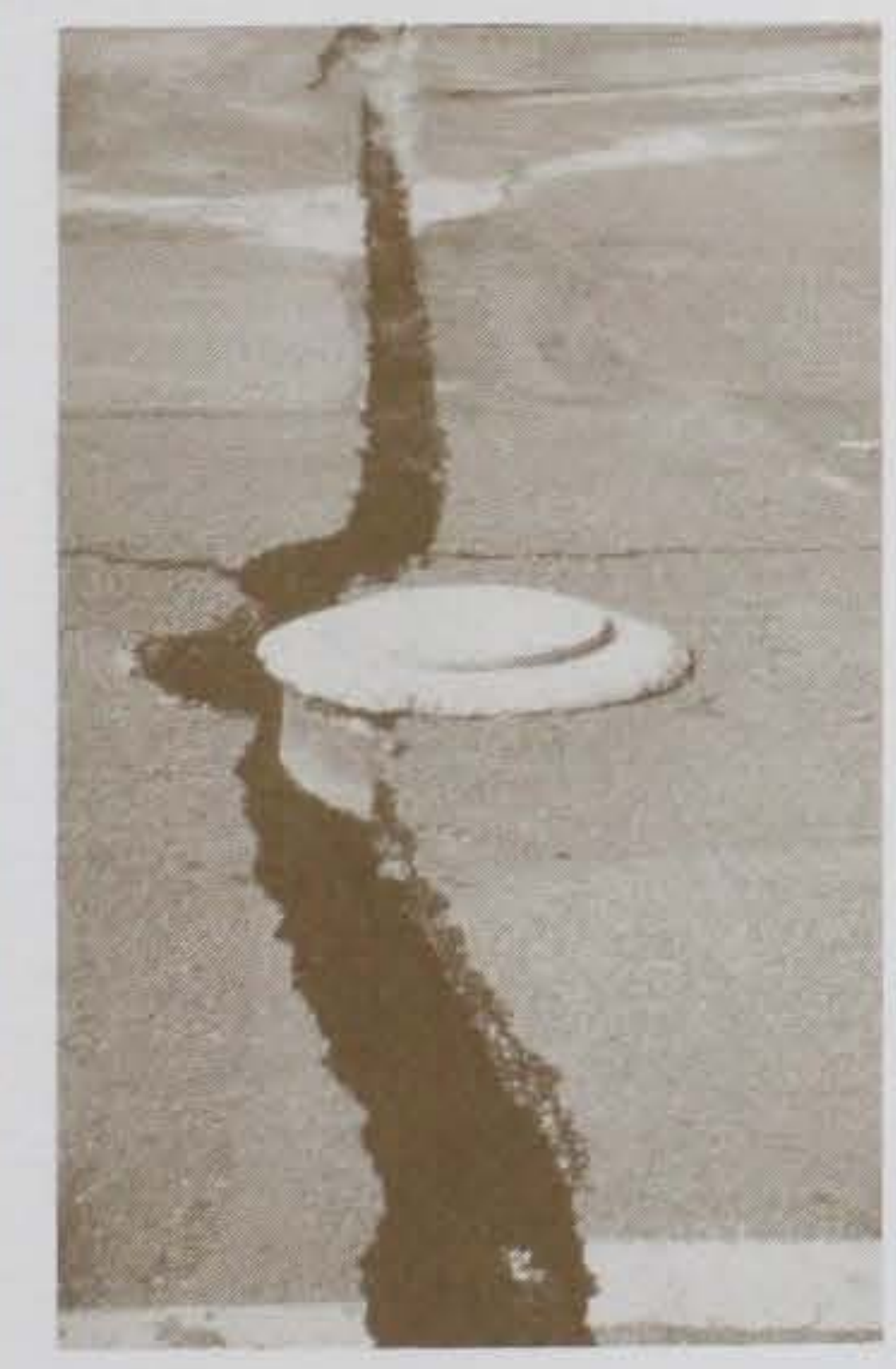

Approved For Public Release; Distribution Is Unlimited

$$
\begin{gathered}
\text { RESEARCH LIBRARY } \\
\text { US ARMY ENGINEER WATERWAYS } \\
\text { EXPERIMENT STATION } \\
\text { VICKSBURG, MISSISSIPPI }
\end{gathered}
$$

Prepared for DEPARTMENT OF THE ARMY

US Army Corps of Engineers

Washington, DC 20314-1000

and

DEPARTMENT OF THE AIR FORCE

Civil Engineering Support Agency

Tyndall Air Force Base, Florida 32403-6001 
Public reporting burden for this collection of information is estimated to average 1 hour per response, including the time for reviewing instructions, searching existing data sources. gathering and maintaining the data needed, and completing and reviewing the collection of information. Send comments regarding this burden estimate or any other aspect of this collection of information, including suggestions for reducing this burden. to Washington Headquarters Services, Directorate for information Operations and Reports, 1215 Jefferson Davis Highway, Suite 1204, Arlington, VA 22202-4302, and to the Office of Management and Budget, Paperwork Reduction Project (0704-0188), Washington, DC 20503.

\begin{tabular}{|l|c|c|}
\hline 1. AGENCY USE ONLY (Leave blank) & $\begin{array}{c}\text { 2. REPORT DATE } \\
\text { July } 1992\end{array}$ & $\begin{array}{c}\text { 3. REPORT TYPE AND DATES COVERED } \\
\text { Final. report }\end{array}$ \\
\hline
\end{tabular}

4. TITLE AND SUBTITLE

Oakland International Airport Caused by the

Loma Prieta Earthquake

6. AUTHOR(S)

Barney A. Vallerga, William P. Grogan

\section{PERFORMING ORGANIZATION NAME(S) AND ADDRESS(ES)}

USAE Waterways Experiment Station

Geotechnical Laboratory

3909 Halls Ferry Road, Vicksburg, MS 39180-6199

B. A. Vallerga Inc., Oakland, CA 94612

9. SPONSORING/MONITORING AGENCY NAME(S) AND ADDRESS(ES)

US Army Corps of Engineers

Washington, DC 20314-1000

US Air Force

Tynda11 Air Force Base. FL 32403-6001

11. SUPPLEMENTARY NOTES

Available from National Technical Information Service, 5285 Port Royal Road, Springfield, VA 22161

12a. DISTRIBUTION/AVAILABILITY STATEMENT

12b. DISTRIBUTION CODE

Approved for public release; distribution is unlimited

\section{ABSTRACT (Maximum 200 words)}

On 17 October 1989, the Loma Prieta earthquake struck near Santa Cruz, CA. Damage occurred as far away as 60 miles from the earthquake's epicenter. Of par. ticular concern was damage to transportation systems such as the Metropolitan Oakland International Airport (MOIA). Approximately 3,000 ft of the MOIA runway was damaged due to the earthquake. This report documents the damage that occurred at MOIA, possible reasons for the damage occurring, the effort that made the damaged portion of the runway operational again, and possible solutions for reducing the susceptibility of the site to damage from future earthquakes.

\begin{tabular}{|c|c|c|}
\hline \multicolumn{3}{|l|}{ 14. SUBJECT TERMS } \\
\hline Density & Epicenter & Metropo \\
\hline Dredged sandfill & Liquefaction & nterna \\
\hline Earthquake & Loma Prieta & \\
\hline $\begin{array}{l}\text { 17. SECURITY CLASSIFICATION } \\
\text { OF REPORT }\end{array}$ & $\begin{array}{l}\text { 18. SECURITY CLA } \\
\text { OF THIS PAGI }\end{array}$ & IFICATION \\
\hline Unclassified & Unclassif & \\
\hline
\end{tabular}

PERFORMING ORGANIZATION

Miscellaneous Paper GL- $92-17$ AGENCY REPORT NUMBER
. SPONSORING / MONITORING 
This study was conducted by the Geotechnical Laboratory (GL), US Army Engineer Waterways Experiment Station (WES), and Barney A. Vallerga, Inc., during the period January 1990 through March 1991. The investigation was sponsored by the Air Force and US Army Corps of Engineers (USACE). The Technical Monitor for the Air Force was Mr. J. Greene, for USACE the Technical Monitor was Mr. Paige Johnson.

The study was conducted under the general supervision of Dr. William F. Marcuson III, Director, GL, Dr. George Hammitt II, Chief, Pavement Systems Division (PSD), GL, and Mr. Jim W. Hall, Jr., Chief, Systems Analysis Branch $(\mathrm{SAB})$, PSD, GL. The study was conducted by Messrs. B. A. Vallerga, B. A. Vallerga, Inc., and W. P. Grogan, SAB, PSD. The report was prepared by Messrs. Vallerga and Grogan.

The details and data that are contained in this report were collected with the invaluable service and information provided by many persons. The Port of Oakland personnel who provided information included Messrs. Roy Clark (retired), Thomas A. Remus, Enrique P. Zommora, Jr., and Gerald M. Serventi. Mr. Mahmut Otus of Geomatrix Consultants, Inc. provided information on subsurface conditions. Mr. J. David Rogers of Rogers/Pacific, Inc. provided information concerning the geology of the Metropolitan Oakland International Airport site.

At the time of publication of this report, Director of WES was Dr. Robert W. Whalin. Commander and Deputy Director was COL Leonard G. Hasse11, EN. 


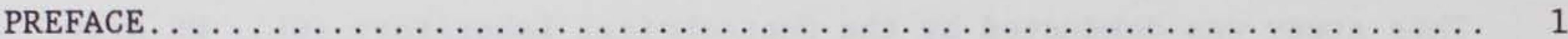

CONVERSION FACTORS, NON-SI TO SI (METRIC)

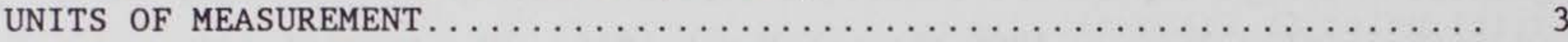

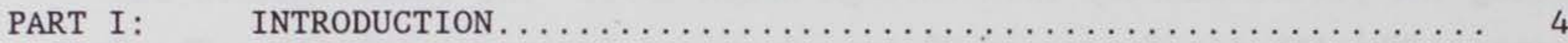

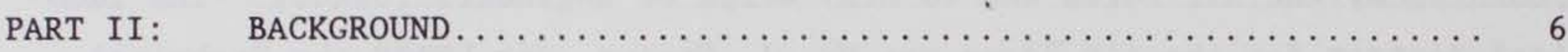

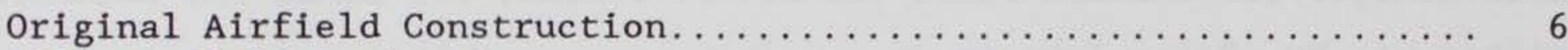

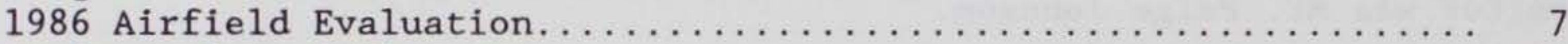

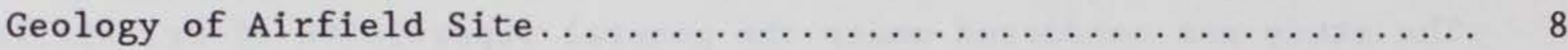

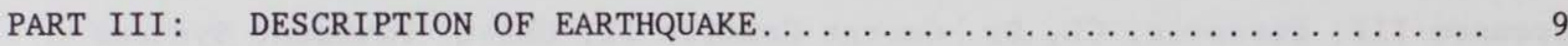

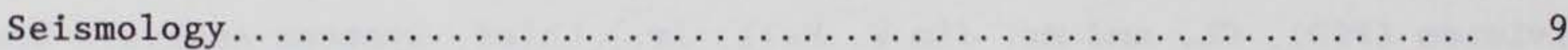

Description of Earthquake Damage..................... 9

Geotechnical Failures.......................... 10

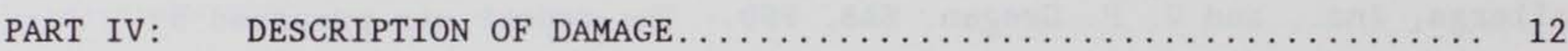

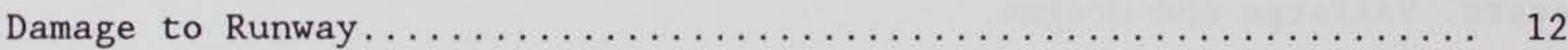

Damage to Other Airport Facilities.................... 12

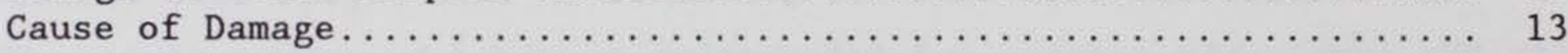

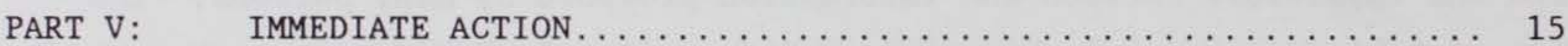

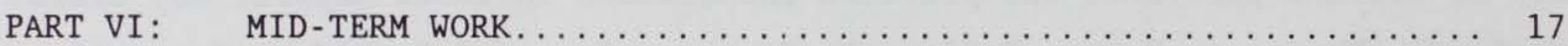

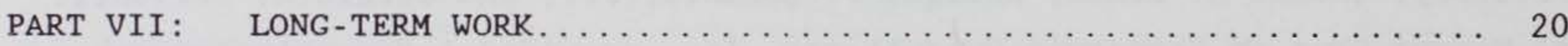

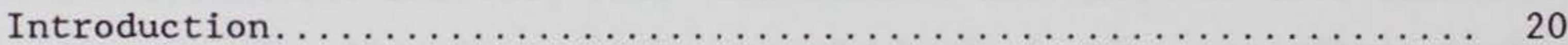

Factors Affecting Liquefaction Potential................. 20

Approaches to Reduce Liquefaction Damage.................. 22

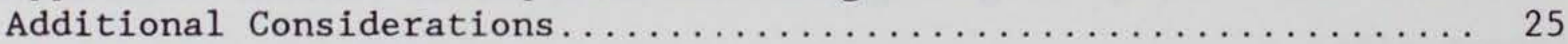

PART VIII: $\quad$ SUMMARY OF LESSONS LEARNED $\ldots \ldots \ldots \ldots \ldots \ldots \ldots \ldots \ldots \ldots \ldots \ldots \ldots \ldots \ldots \ldots \ldots$

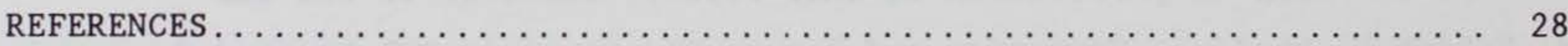

FIGURES 1-22 


\section{CONVERSION FACTORS, NON-SI TO SI (METRIC) \\ UNITS OF MEASUREMENT}

Non-SI units of measurement used in this report can be converted to SI (metric) units as follows:

\begin{tabular}{|c|c|c|}
\hline Multiply & By & To Obtain \\
\hline degrees (angle) & 0.01745329 & radians \\
\hline feet & 0.3048 & metres \\
\hline inches & 2.54 & centimetres \\
\hline miles (US statute) & 1.609347 & kilometres \\
\hline pounds (mass) per cubic foot & 16.01846 & kilograms per cubic metre \\
\hline tons $(2,000$ pounds, mass $)$ & 907.1847 & kilograms \\
\hline
\end{tabular}




\section{A CASE STUDY: DAMAGE TO THE METROPOLITAN OAKLAND}

\section{INTERNATIONAL AIRPORT CAUSED BY THE LOMA}

\section{PRIETA EARTHQUAKE}

\section{PART I: INTRODUCTION}

1. On 17 October 1989 the Loma Prieta Earthquake took place near Santa Cruz, CA. Damage occurred as far as 60 miles* from the earthquake's epicenter. Of particular concern was damage to transportation systems and widespread disruption of utilities and lifeline facilities. Damage to airports in the vicinity of a major natural disaster, such as the Loma Prieta Earthquake, is critical since airports are a major link in our national transportation system that can deliver emergency supplies and help. Relevant seismological information concerning the Loma Prieta earthquake was obtained from a comprehensive report by Mr. Raymond B. Seed (1990) entitled, "Preliminary Report on the Principal Geotechnical Aspects of the 17 October 1989 Loma Prieta Earthquake," published by the Earthquake Engineering Research Center, College of Engineering, University of California at Berkeley, Report No. UCB/EERC-90/05, April 1990.

2. The Army and the Air Force are particularly concerned with maintaining the operational capabilities of military airfields following natural disasters and understanding the degradation of military capability that occurs. The Army and the Air Force maintain airfields throughout the world, and many of these airfields are located in earthquake prone regions.

3. An investigation into a case history such as the damage that occurred at the Metropolitan Oakland International Airport (MOIA) provides valuable experience. The damage that occurred to the runway pavement at MOIA was a result of liquefaction occurring in an underlying zone of dredged sandfill. Only the western 3,000 ft of the 10,000-ft runway (Runway 11-29) was damaged. Figure 1 shows the general layout of the MOIA in relationship to the San Francisco-Oakland Bay area. Figure 2 is a plan view showing the areas of

* A table of factors for converting non-SI units of measurement to SI (metric) units is presented on page 3. 
the MOIA airfield runway pavement that had to be repaired due to cracks as a result of the Loma Prieta Earthquake. This report presents and discusses the conditions that lead to the failure of the $3,000 \mathrm{ft}$ of runway, describes the damage which occurred, recites what was done to repair the runway, and gives an overview of possible solutions to reduce the susceptibility of the airfield to damage in the event of a future earthquake. 


\section{PART II: BACKGROUND}

\section{Original Airfield Construction}

4. The entire length of Runway 11-29 at MOIA is constructed on an approximately 12- to 15-ft-thick layer of hydraulically dredged sandfill. The fill underlying the runway was constructed in approximately four stages. Stage 1, before 1954, was accomplished by the construction of a dike to enclose the area to be filled with hydraulically dredged sand.

5. Stage 2 construction, 1954 to 1955, consisted of removing the west end of the dike, placing the hydraulically dredged sandfill, and then reconstructing the west end of the dike. The west end of the dike was removed to allow for a larger area than originally planned to be filled for future expansion of the runway from 8,500 to $10,000 \mathrm{ft}$. With the west end of the dike removed, the area was filled at low tides. The high tides evenly spread the dredged sandfill placed at low tides, and washed laterally some of the excess fines. The fill was placed from sta $86+00$ to the east, then from sta $86+00$ to the west, over the excavation where the original dike had been, to the location of the new dike which was then constructed. No density requirement was specified, and no effort was made to densify the fill, other than the operation of the equipment used to place the fill.

6. In 1955 the Stage 3 construction was accomplished. The top $3 \mathrm{ft}$ of the dredged fill was densified to a dry density requirement of $105-1 \mathrm{~b} / \mathrm{ft}^{3}$ to provide support for the 8,500 - by 150 -ft runway to be constructed.

7. Stage 4 construction, 1964, consisted of densifying the top $3 \mathrm{ft}$ of the dredged fill to a dry density of $105-1 \mathrm{~b} / \mathrm{ft}^{3}$ to provide support for the 1,500 by 150 -ft runway extension to be constructed.

8. A cross section of the airfield through the dike, the runway, and the taxiway is shown in Figure 3. Figure 3 shows some critical items that make this site susceptible to liquefaction damage. The relatively loose hydraulic sandfill with a high water table over bay mud on medium to dense sands or stiff silty clay makes the MOIA site vulnerable to liquefaction. The layers underlying the fill intensified the ground shaking helping to cause the sandfill to liquefy. The mean high sea level at $5.8 \mathrm{ft}$ maintains a high water table in the sandfill. Typically the water table is approximately 7 to $10 \mathrm{ft}$ 
below the top of the pavement. This high water table would facilitate the liquefaction of the sandfill.

\section{Airfield Evaluation}

9. The structural capacity of Jet Runway 11-29 at the MOIA was investigated in 1986, 3 years before the Loma Prieta Earthquake. The results of the evaluation were documented in a report by B. A. Vallerga Inc. entitled, "Pavement Overlay Design Study Jet Run-way 11-29, South Field, Metropolitan Oakland International Airport," dated January 1986 (Vallerga 1986). The structural evaluation was based on visual observations of the present pavement condition and on results of surface deflection measurements using the Benkelman Beam procedure. The pavement structure at the time of the evaluation consisted of an 8-to 12.5-in. AC layer supported by a 7- to 10-in. aggregate base. The aggregate base was constructed on dredged sandfill. The water table is approximately 7 to $10 \mathrm{ft}$ below the pavement surface.

10. The 1986 evaluation revealed that the structure of the east portion of the runway, which was not damaged during the earthquake, was in need of a substantial structural upgrade to sustain the projected 10-year runway traffic. The west end of the runway was found to be structurally adequate for its design traffic as the prevailing winds result in only 10 percent of landing and takeoff rolls occurring from the west. There were some shrinkage cracks along the entire length of the runway, primarily at longitudinal construction joints because of aging. The 1986 report called for an overlay of 7.5 in. of hot mix asphalt concrete $(A C)$ between sta $4+00$ and $20+00$ and an overlay of 4.5 in. of $\mathrm{AC}$ between sta $20+00$ and $43+00$. After the structural overlay, the report recommended a 1.0 in. porous friction course (PFC) made with an asphalt-rubber binder $(A-R)$ be constructed over the entire runway to provide a more durable runway surface uniform in surface texture and appearance with draining characteristics which would preclude the need for grooving.

11. The report also noted that the AC overlays required between sta $4+00$ and $43+00$ could be reduced by $0.5 \mathrm{in}$. if the A-R PFC were constructed over this portion of the runway. At the time of the earthquake, the 
structural overlays had been completed and the A-R PFC had been completed to sta $78+00$.

\section{Geology of Airfield Site}

12. An interesting geologic feature may have added to the susceptibility of the west end of the runway to liquefaction. A map entitled "Contours on Bottom of Young Bay Mud", found in the California Division of Mines and Geology (CDMG) Special Report 97, shows the Late-Pleistocene topography before the rising sea levels and the deposition of the Young Bay Muds. Figure 4 shows the topography around the airport from CDMG Special Report 97 with some interpolations. The contours in Figure 4 show the San Leandro Creek channel crossing the western end of the MOIA Runway 11-29. The deeper Young Bay Muds (Rogers 1990) in this area would lead to lengthened site periods and amplified strong motion components. The strong motions resulting from this deeper mud would provide for more intense ground shaking in the liquefaction susceptible soils underlying the western part of the runway than under the eastern part. Liquefiable soils underlie the entire runway, but the increased ground motion in the area of the deeper muds may have made the west end of the runway more vulnerable to liquefaction damage than the rest of the runway. 


\section{$\underline{\text { Seismology }}$}

13. On 17 October 1989 at 5:04 p.m. local time, an approximately 24-mile segment of the San Andreas fault ruptured (Seed 1990). The event had a Richter magnitude of 7.0 (measured by the Seismographic Stations at the University of California at Berkeley) and a surface wave magnitude of 7.1 (measured by the U.S. Geological Survey). The epicenter was 50 miles from the MOIA site. The epicenter was located approximately 10 miles northeast of Santa Cruz and 20 miles south of San Jose, at 37.037 deg north latitude and $121.883 \mathrm{deg}$ west longitude.

14. The rupture occurred along the southernmost part of the segment of the San Andreas fault that ruptured during the catastrophic 8+ magnitude 1906 San Francisco earthquake. Figure 5 shows the epicenter of the Loma Prieta earthquake in relation to the San Francisco-Oakland Bay area (Seed 1990).

15. The earthquake had a short duration for this magnitude of earthquake. There was only about 8 to $10 \mathrm{sec}$ of strong shaking during the main rupture. One of the reasons for the unusually short duration of shaking was the central location of the hypocenter, or focus of the earthquake, within the rupture zone. The main rupture spread approximately 12 miles to the north and 12 miles to the south along the fault during the 8 to $10 \mathrm{sec}$ event. The relatively few loading cycles that resulted undoubtedly had a beneficial effect on the region by not causing more damage than would have resulted from a greater number of loading cycles.

16. The aftershock sequence following the main event was typical of major California earthquakes. There were a total of 87 aftershocks of magnitude 3.0 or greater in the 3 weeks following the initial event.

\section{Description of Earthquake Damage}

17. The Loma Prieta earthquake has been labeled as the most costly single natural disaster in US history (Seed 1990). There were 62 fatalities directly related to the earthquake, and there are estimates of between 6 and 10 billion dollars worth of damage directly attributable to the earthquake. 
Business revenue and personal income losses were not included in the estimates.

18. Several reasons contributed to the limited death toll resulting from the earthquake which would have undoubtedly claimed more lives. Thirty eight deaths were caused by the collapse of the elevated Cypress section of Interstate 880 in Oakland. Fortunately, rush hour was relatively light on the evening of the earthquake because many commuters had gone home early to watch the third game of the World Series of Baseball between the Oakland A's and the San Francisco Giants. It was also fortunate that the earthquake was centered in a relatively remote, sparsely populated area and had a short duration. The remote location of the ruptured fault segment along with the unusually short duration limited injuries to people and damages to structures and facilities.

\section{Geotechnical Failures}

19. There were three main types of failures related to the geotechnical aspects of structures as a result of the Loma Prieta Earthquake. The first type of failure was site specific, i.e. the area where a failure occurred was particularly susceptible to the effects of loadings applied from ground shaking and fracture as a result of the earthquake. The structures located on these sites could not withstand the ground motions that occurred because of the loading from the earthquake. These areas, such as the Cypress I-880 elevated highway, were usually underlain by deep deposits of Bay mud as they are known locally. This soft highly compressible clay and silty clay material is extremely vulnerable to the shaking induced by the bedrock on which it is founded. In some areas the depth of the Bay mud may be as great as $100 \mathrm{ft}$. The soft clay actually amplified the shaking caused by the earthquake which resulted in large horizontal movements at the surface. Large horizontal movements resulted in the collapse of a section of the San Francisco-Oakland Bay bridge. The section of the Bay bridge that failed was supported on a 5-in. wide bracket. When the horizontal movement of the bridge exceeded 5 in. and sheared the bolts securing the support to the bracket, the section collapsed.

20. The second type of geotechnical failure associated with the earthquake was landslides. Landslides resulted in closing many roads and highways as well as the destruction of buildings. Again, due to the fairly remote 
location of the fault zone, the majority of structural damage was confined to single family dwellings. There were about 800 to 1,000 structures damaged or destroyed by landslides. Landslide damage occurred as far as 60 miles north and 30 miles south of the rupture zone.

21. The third type of failure commonly found in the area was liquefaction. Liquefaction is caused when a deposit loses its shear strength due to the increase in pore water pressure. When the pore pressure increases to the point where it equals the total stress, the effective stress becomes zero and the soil mass behaves as a liquid. This is primarily the type of failure that occurred at the MOIA. Figure 5 shows the areas in the east bay that suffered liquefaction failures. Sites in the bay area that suffered from liquefaction failure had some characteristics in common; they were usually hydraulically placed or dumped sandy fills overlying bay muds with a high water table. The bay muds underlying sandy deposits exaggerated the earthquake-induced horizontal movements. The strong horizontal motions caused liquefaction to occur. Fill areas overlaying bay mud are not the only areas susceptible to liquefaction. However, the loose, saturated fills overlying the bay mud were more susceptible which is why failure occurred in these areas more readily than in other areas. If the earthquake had a longer duration, many other sites and much more damage would have been expected. Liquefaction damage would likely have occurred over a greater areal portion of the MOIA site if the duration of the earthquake loading had been longer than 8 to $10 \mathrm{sec}$. 


\section{Damage to Runway}

22. Approximately 3,000 $\mathrm{ft}$ of the west end of Runway 11-29 of the MOIA was damaged as a result of the Loma Prieta Earthquake. The damage included sand boils, together with cracking and buckling of the pavement, which resulted in vertical and lateral displacements at the surface. There were lateral displacements as large as $12 \mathrm{in}$. and vertical displacements up to $8 \mathrm{in}$. The west end of the runway shifted more than $2 \mathrm{ft}$ to the south. Figure 6 shows the lateral spreading the runway experienced. The values noted along both edges of the runway in Figure 6 are measured from the center line; the center line was reestablished from the undamaged portion of the runway. The edges had been at a distance of $100 \mathrm{ft}$ before the earthquake. The elevation of the runway was also altered by the earthquake. Figure 7 shows the runway profile before and after the earthquake along the center line and at 75-ft offsets. From Figure 7, it can be seen that the high points generally dropped in elevation causing the pavement to buckle and/or rise at the low points.

23. The majority of the cracks that formed in the pavement as a result of the earthquake followed joints in the pavement and then skewed off at various angles until they met another joint which they would then follow. Figures 8 and 9 show where the cracks followed construction joints in the AC pavement. Figure 10 shows a transverse crack, which did not follow a joint. Figure 11 shows a longitudinal crack; one side of the crack dropped in elevation significantly greater ( $8 \mathrm{in}$ ) than the adjacent side of the crack. It should be noted that the 8 -in.-thick, 15-year old AC pavement, showing signs of embrittlement, deformed $8 \mathrm{in}$. over a span of $11.2 \mathrm{ft}$ without visible surface cracking at the location shown in Figure 11. Sand boils formed at many cracks. Figures 12 and 13 show sand boils that formed.

\section{Damage to Other Airport Facilities}

24. In addition to the damage to the pavement of Runway 11-29, some runway lights were also affected. All air traffic was directed to alternate 
Runway 09R-27L at the Oakland airport's North Field, delegated to emergency use only for jet traffic. It was virtually undamaged. The west end of Taxiway 1 , which runs parallel to Runway 11-29, was damaged in a manner similar to the runway. There was also some relatively minor damage to some of the airfield apron pavements, which remained serviceable and were kept in operation.

25. The MOIA is protected from the San Francisco Bay by a dike. The earthquake caused the dike to subside and crack in a few locations, causing concern for the safety of those areas at low elevations, including the runway, but the dike was not breached.

26. The MOIA Terminal I building was damaged. Falling plaster and light fixtures, ringing fire alarms, and cracks opening up in the ceiling made it prudent to evacuate Terminal I until the safety of the building could be assessed. The Terminal II building received only minor damage and was used until the Terminal I building was deemed safe and reopened for use. Terminal I was reopened only $2 \mathrm{hr}$ after the earthquake occurred.

\section{Cause of Damage}

27. The main cause of damage to the west end of Runway 11-29 at the MOIA was liquefaction of an underlying layer of saturated, relatively loose, uniformly graded sand which has a propensity to liquefy. There were several contributing factors that caused the liquefaction of this underlying layer of soil. The contributing factors included a high water table, inadequate compaction of underlying fill material, the size characteristics of the material itself, and the geology of the area.

28. Because the MOIA site is directly adjacent to the San Francisco Bay, the water table would be expected to be high. The elevation of the runway surface is only between 6 and $8 \mathrm{ft}$ above mean sea level, and only 0.2 to $2.2 \mathrm{ft}$ above mean high sea level of $5.8 \mathrm{ft}$. Figure 2 shows a cross section through the airfield, including the dike that protects the airfield. The cross section in Figure 2 indicates that the water table is sufficiently high so as to saturate the lower half of the hydraulically dredged sand fill.

29. At the time of the Loma Prieta Earthquake (17:05 hr) the tide was $3.94 \mathrm{ft}$, which is somewhat above the mean tide of $3.25 \mathrm{ft}$. It is interesting to note that the tide was falling at the time of the earthquake from a high 
tide of $6.97 \mathrm{ft}$ at $1400 \mathrm{hr}$. Figure 14 shows the recorded rise and fall of the tide on 17 October 1989.

30. The fill material on which the last 3,000 ft of runway was constructed was placed at the same time as the fill for the rest of the runway. However, the area that is now the last 1,500 ft of runway was originally an overrun area. When fill was placed for the overrun area, the depth of fill was deeper, 7 to $11 \mathrm{ft}$, in part of this area because of the dike that was originally built in this area and then removed. The additional depth of liquefiable material may have been a contributing factor which caused the west end of the runway to liquefy.

31. The material used as fill is a uniformly graded sand as shown in Figure 15. The uniformity of the gradation makes the material extremely vulnerable to the phenomena of liquefaction. The gradation of the fill material falls within the region of materials most sensitive to liquefaction (Bhandari 1981).

32. A final contributing factor causing the last $3,000 \mathrm{ft}$ of runway to sustain damage was the geology of the area. As shown in Figure 3, the last part of the runway was constructed over an area of mud deeper than that over which the rest of the airfield was constructed. This difference in geology led to a different response to the earthquake loading.

33. The high water table, increased depth of deposition of fill material, uniform gradation of fill material, and geology of the site all contributed to explaining why the west 3,000 ft of Runway 11-29 at the MOIA failed while the remainder did not. 


\section{PART V: IMMEDIATE ACTION}

34. Immediately following the earthquake, a visual inspection of the runway was made. The condition survey indicated that the damage was confined to the western $3,000 \mathrm{ft}$ of runway and that no visual damage existed in the first $7,000 \mathrm{ft}$ of the $10,000-\mathrm{ft}$ runway. From the initial visual survey, the useable length of the airfield was shortened to $6,500 \mathrm{ft}$.

35. Following the visual ground survey, ground and aerial photos were taken to record the damage that occurred as a result of the earthquake. A topographic survey of the damaged area was run on a $25-\mathrm{ft}$ grid to determine the extent of grade changes. Deflection data were taken with the Benkelman Beam to compare to data that were taken 3 years previously (1986). Results of the Benkelman Beam tests showed that the deflections were not significantly different than those from the 1986 results except for measurements directly adjacent to the cracks where the deflections were substantially larger. Figure 16 compares the deflection measurements before and after the earthquake and illustrates the increase in deflections immediately adjacent to the earthquake-induced cracks.

36. Following the Benkelman Beam tests, a crack was excavated to determine what might be expected under the pavement. Figure 17 shows the top of the excavation of a crack that was associated with a sand boil. A slight void is shown under the pavement AC surface at the edges of the crack in Figure 18 where the base material sloughed off into the crack. Figure 19 shows the crack further down. The crack can be followed down a distance of a couple feet, but then it becomes indistinguishable from the surrounding material. From this excavation and the Benkelman Beam deflections, it was concluded that there would probably not be any cavities found under the pavement except at both sides of the earthquake-induced cracks immediately below the asphalt concrete paving.

37. To ensure there were no cavities or weak spots, a 50-ton proof roller was used to proof roll the pavement as shown in Figure 20. Three coverages of the proof roller were made over the full 150 -ft width over the 3,000-ft long earthquake damaged portion of the runway. There were no weak spots or cavities detected anywhere by the proof roller except directly adjacent to cracks where the base course had sloughed off into the cracks that had 
formed at the time of the earthquake. Figure 21 illustrates a typical area of broken pavement adjacent to an earthquake crack produced by proof rolling.

38. There were some minor cracks in the runway from sta $65+00$ to $70+00$. These minor cracks were filled with a cement grout and the first 7,000 ft of runway was then opened for use. 
39. After the initial evaluation and determination that 7,000 $\mathrm{ft}$ of Runway 11-29 at the MOIA was useable, the Oakland Port authority began working to make the entire runway operational. The air-cargo carriers, which are predominant users of the airfield, were having to reduce loads because of the limited take-off distance. The holiday season was approaching with the demand for larger loads due to the increased number of packages being shipped. The air-cargo carriers were particularly anxious to have the entire length of the runway operational by Thanksgiving Day, November 23, 1989.

40. The initial evaluation following the earthquake consisted of deflection tests with the Benkelman Beam and proof rolling with a 50 -ton roller. From the initial evaluation, it was determined that the visually undamaged portions of the pavement were still structurally adequate to support the design traffic. Once the structural concerns were satisfied for the visually undamaged portions of the runway, the damaged portions of the runway could be addressed. The problems resulting from the earthquake were not only structural, but were also operational in nature. Aircraft could not operate on a runway with large cracks and vertical displacements as large as 8 in.

41. A local paving contractor, O. C. Jones \& Sons, was under contract with the Port Authority of Oakland at the time of the earthquake. The contractor was in the process of completing the rehabilitation of Runway 11-29 by placing the A-R PFC. The Port Authority negotiated an emergency change order with the contractor to repair the damaged runway and then finish the construction of the A-R PFC using the same specifications and unit prices for materials and equipment as used in the rehabilitation contract.

42. The repairs to the runway were done in two phases. Phase one involved the repairs to the runway between sta $65+50$ and $90+00$. Phase two involved the repairs to the runway between sta $90+00$ and $100+00$. The repairs were done in two phases because the Port Authority had to get a minimum of $8,500 \mathrm{ft}$ operational by Thanksgiving. The last $1,000 \mathrm{ft}$ of the runway was more extensively damaged than the rest of the damaged portion of the runway and would require more time to repair.

43. Because of the demanding time constraint for making the runway operational, the inspection of the runway and writing of the plans and 
specifications for repairs to the runway had to be done expeditiously. The Port of Oakland engineering design branch developed a standard repair detail as shown in Figure 22. The standard repair detail was modified in the field as necessary and as directed by the Port of Oakland construction engineer.

44. The repair of cracks in the runway as shown in Figure 22 consisted of the removal and disposal of the $A C$ and base course directly adjacent to the crack. The subgrade was removed from around the crack, replaced, and recompacted to ensure adequate density where the crack had been. New base course was then constructed and an AC layer was constructed on the base course.

45. The depth and width of repairs to the subgrade were based on the characteristics of the crack encountered. Cracks less than 4 in. wide were generally excavated to a depth of 4 or $5 \mathrm{ft}$. Cracks wider than $4 \mathrm{in}$. were excavated a minimum of $6 \mathrm{ft}$ deep. Cracks that had both vertical and horizontal displacements were generally excavated to a depth of at least $6 \mathrm{ft}$. The width of subgrade excavation was a minimum of $6 \mathrm{ft}$ to allow for the use of steel wheel minicompactors. The minicompactors were lowered into the excavation and worked up from the bottom of the excavation on approximately 6-to 8 -in. lifts of the replaced and compacted subgrade. Cracks that were skewed from vertical were generally excavated wider than $6 \mathrm{ft}$ to ensure that enough subgrade material was removed and replaced around the crack. Multiple cracks that were close together were excavated as one crack, making the excavation wider than $6 \mathrm{ft}$. The subgrade was brought up to approximately $2 \mathrm{in}$. below the top of the adjacent subgrade layer. The subgrade was left $2 \mathrm{in.}$ low to allow for a 2 in. increase in thickness of the AC in the repair sections. Although the depth of the AC was to be increased in the areas of crack repair by approximately 2 in., the thickness of the new base was to remain the same as the thickness of the adjacent undisturbed base course. The increase in thickness of the $A C$ was to ensure adequate structural capacity of the pavement.

46. An aggregate base course was constructed on the newly compacted subgrade. The base course was stepped back a minimum of $1 \mathrm{ft}$ on each side of the subgrade repair. The step back would prevent the construction of a vertical joint through the depth of the pavement into the subgrade. The thickness of the new aggregate base course was to be approximately equal to the depth of the existing adjacent base course. The aggregate base course was compacted with steel wheel minicompactors as the subgrade had been. 
47. The AC layer was to be stepped back a minimum of $1 \mathrm{ft}$ on each side of the base course repair. The step back was to preclude the formation of a vertical joint in the pavement. The width of the excavation for placement of the $\mathrm{AC}$ had to be at least $11.5 \mathrm{ft}$ wide. The minimum width was required because an asphalt paver was to be used to place the AC into the excavations to be repaired. The asphalt paver required a minimum of $11.5 \mathrm{ft}$ width in order to operate. Pavers were used for placement of the AC layer to provide a more uniform layer than would have resulted if the AC had been placed by hand.

48. After the repair of cracks, there were still irregularities in the pavement that had to be fixed. A nominal 3 -in. AC overlay was placed over the entire full width area of the earthquake damaged portion of the runway to ensure that the final surface could be placed to the desired grade and smoothness tolerance criteria. Areas that were significantly out of tolerance were corrected prior to the placement of the 3-in. overlay. Locations that were high and would not allow for the placement of at least 2 in. of AC and remain within grade tolerances were milled. Locations that were low and would have required more than 4 to 5 in. of the nominal 3 -in. overlay were plugged. The maximum aggregate size used for the plugging mix was $0.5 \mathrm{in.}$ The 0.5 in. maximum size allowed the plug to be feathered at the edges. The maximum aggregate size for the 3 -in. overlay was 0.75 in. After the construction of the 3 -in. nominal AC course, the 1 -in. A-R PFC that the paving contractor had been in the act of placing at the time of the Loma Prieta Earthquake was finally constructed.

49. The contractor undertook the work with diligence, using double work shifts and overtime as needed. Quality control tests were carried out under the supervision of Port Engineers and Consultants. All repairs between sta $65+00$ and $90+00$ were completed well within the time constraint of Thanksgiving Day, 23 November 1989. The first 8,500 ft of Runway 11-29 was made operational on 15 November 1989. 
PART VII: LONG-TERM WORK

\section{Introduction}

50. Following the completion of repairs to Runway 11-29 at the MOIA, the question remains as to the susceptibility of the site to future earthquake damage. The Loma Prieta Earthquake was not of a magnitude or proximity to the bay area to be considered a true test of the response of the MOIA site to loadings that would be imposed by a maximum credible earthquake. It would be prudent to investigate measures for reducing the risk of future earthquake induced damage to the airfield pavements as well as its other facilities at MOIA.

51. The type of failures that occurred at the MOIA were liquefaction induced ground settlement and lateral spreading. During ground settlement, the soil densifies as it reconsolidates. The reconsolidating liquefied soil produces ground settlement accompanied by fissures and sand boils (Bartlett and Youd 1990). Sand boils as illustrated in Figures 12 and 13 are a result of liquefaction-induced ground settlement. During lateral spreading, surface soil layers displace down gentle slopes. The surface soils ride on a subsurface shearing zone where the soil strength has been reduced by a rise in pore water pressure. The lateral displacement may be caused by gravitational or seismic inertial forces, or both. The soils overlying the liquified zone may retain their strength and ride passively on the underlying weakened soil or may experience significant strength loss and brittle cracking. The elevations along the length of the runway before and after the earthquake shown in Figure 7 reveal some lateral spreading characteristics. The high points in the runway cracked and dropped in elevation, and the low points show signs of buckling (see Figure 11).

\section{Factors Affecting Liquefaction Potential}

52. The main factors controlling the resistance of a site to liquefaction can be separated into two categories: those factors related to the applied earthquake load and those factors related to the available cyclic strength of the deposit. The factors related to the earthquake loading, or 
induced cyclic stresses, include the intensity of ground shaking, the duration of ground shaking, and the dynamic response of the site to these motions. Since the earthquake cannot be controlled or altered, and any significant change in the fundamental period of a site is difficult to achieve, the factors related to the cyclic strength of a site must be investigated for modification. The factors that are related to the available cyclic strength of a site include: (a) soil type and characteristics, (b) relative density, (c) initial confining pressure (both $\sigma$ and $\tau$ ), and (d) degree of saturation.

53. The soil type of a site in an earthquake zone should be investigated for vulnerability to strength loss and deformation because of earthquake activity. Different soil types behave differently when subjected to the loadings induced by an earthquake. Although many soil types may be susceptible to liquefaction, some soil types are more vulnerable than others. Soil characteristics such as age and fabric also affect the way a deposit will perform under an earthquake induced load. Any structure to be constructed in an earthquake prone region should be designed to withstand the expected behavior of the soil on which it is founded. The expected behavior of the soil should be evaluated based on the design earthquake and the soil type and characteristics at the site. At the MOIA, it is known that the soils are vulnerable to liquefaction because of the damage that occurred as a result of the Loma Prieta Earthquake. The site of the MOIA is also known to be vulnerable to liquefaction because the fill materials are relatively uniform, fine sands placed hydraulically. A hydraulically placed, uniformly graded sand soil type is particularly susceptible to liquefaction. Figure 15 (the results of a sieve analysis) shows that the dredged subgrade soil at MOIA is quite uniform in particle size.

54. An increase in confining pressure or density reduces a site's susceptibility to liquefaction. Earthquake produced liquefaction in saturated cohesionless soils is the result of excess pore water pressure built up because of cyclic shear stresses induced by the ground motions (Seed 1979). The applied cyclic shear stresses cause the cohesionless soil to try to densify. As the structure of the soil tries to compact with no drainage allowed, there is a stress transfer from the soil grains to the pore water. As the pore water pressure increase approaches a value equal to the applied 
confining pressure, the cohesionless soil begins to undergo deformations. If the cohesionless soil is loose, the pore pressure will increase suddenly to a value equal to the applied confining pressure, resulting in large deformations. If the cohesionless soil is dense, the soil may develop a residual pore water pressure equal to the confining pressure at the end of a stress cycle, but on the next stress cycle, the soil tends to dilate. When the cohesionless soil dilates, the pore pressure drops and the soil develops enough resistance to withstand the applied stress. However the dense cohesionless soil does experience some deformation to resist the applied stresses. The amount of deformation will increase with increases in duration and magnitude of stress cycles. When the applied stress cycles are great enough, the amount of deformation in the dense soil can become significant enough to cause damage. The deformations in a dense soil are generally significantly less than a comparable type soil loosely deposited and subjected to the same cyclic stresses. Increasing the confining pressure increases the cyclic stresses required to cause the pore pressure to equal the confining pressure. Therefore, densification and increasing the confining pressure result in improved site performance in the event of applied cyclic stresses induced by an earthquake. The improved site performance is due to the larger required magnitude and duration of applied cyclic stresses to induce liquefaction.

55. The degree of saturation of a deposit is also an important factor in the liquefaction susceptibility of a site. If there is no water in a system, or the degree of saturation is low, liquefaction is not likely to occur. However, the injection of air or the removal of water from most systems is not a viable solution. The MOIA site would be particularly difficult to permanently dewater. At the MOIA, the surface of Runway 11-29 is at an elevation of between 7 to $8 \mathrm{ft}$ above mean sea level.

\section{Approaches to Reduce Liquefaction Damage}

56. In order to make the MOIA (or any site subject to liquefaction) less vulnerable to earthquake damage, there are four broad categories of pos-

sible approaches. The four approaches include (a) increase the density of the soil, (b) increase the initial confining pressure, (c) use particulate or chemical grouting to increase the stiffness and fill the voids between the 
soil particles, and (d) provide protection to the structure while liquefaction is allowed to occur (Ledbetter 1985). The first three approaches improve the soil conditions to reduce the chance of liquefaction.

57. Densification is the most commonly used procedure for reducing a site's susceptibility to liquefaction. Densification makes the cohesionless soil less vulnerable by requiring a greater duration and magnitude of loading before liquefaction will occur than would be required if the soil was looser. Densification also reduces the potential for large deformations even if high pore pressures develop. Ideally, the earthquake will be of a magnitude and duration that the stress cycles will not reach the critical value and thereby cause liquefaction.

58. Increasing the initial confining pressure of a deposit also results in an increase in cyclic stresses, magnitude and duration of loading required to cause liquefaction. Increasing the initial confining pressure can be accomplished by increasing the overburden. Densification also increases the confining pressure which must be overcome for liquefaction to occur.

59. The approach of grouting a deposit provides adhesion, fills the voids between the soil particles, or can be used for compaction. By providing adhesion, the grout makes the soil act as one solid mass rather than discrete particles. When the material acts as discrete particles, their intergranular contact pressure goes to zero when the pore pressure is great enough. When the intergranular pressure is zero, the soil mass acts as a liquid. The adhesion provided by the grout prevents the intergranular pressure from becoming zero, thereby preventing liquefaction from occurring. By filling the voids, the grout prevents the discrete soil particles from reorienting into a denser state. The prevention of densification also prevents the transfer of stress from the soil grains to the pore water, thereby preventing liquefaction. Grouting can also be used for compaction. Compaction grouting increases the sites resistance to liquefaction by increasing the density and initial confining pressure of the deposit.

60. The final approach involves providing protection to structures while liquefaction is allowed to occur. This alternative is not likely to be applicable to airfield pavements. The tolerances for deformations on airfield pavements is very small. An earthen dam may be able to withstand some subsidence or movement without loosing its pool and would not be considered failed. 
However, a few inches of displacement on an airfield runway may render it useless, and it would be considered failed.

61. Although drainage was not included as one of the broad approaches for reducing a site's vulnerability to liquefaction, it does merit some discussion. Drains can reduce the water table or provide a place for the excess pore water to escape at the time of an earthquake. Liquefaction results from pore water pressure increasing above a critical value. The provision of drains can reduce the amount of water in the system to the point where there is not enough water to allow pore pressures to build up to the critical value. Drains may also provide a path of escape for excessive pore water which is under pressure due to the cyclic loading of an earthquake. Drains can reduce the water in a system; however, at most sites this would require constant pumping and/or maintenance. Biological fouling and infiltration of fines must be prevented in stone columns or other drains intended to provide an escape for pore water under pressure if they are to function properly. The maintenance and energy requirements that would be necessary to keep most sites operational in terms of drainage ability are generally not available, and if provided, the requirements would be difficult to perpetuate.

62. There are several methods for accomplishing each of the approaches discussed. The viable solutions are site dependent. Most of the methods for reducing a site's susceptibility to liquefaction are very difficult to retrofit to existing structures. Probably the best method for reducing a site's liquefaction potential is to provide adequate compaction/density at the time of initial construction. Another alternative that could have been considered for the MOIA site at the time of construction would have been to use an alternate source of fill. The material used was uniformly graded, making it highly susceptible to liquefaction. An alternate fill less uniformly graded would likely have resulted in much improved resistance to deformation.

63. The options available to reduce the vulnerability of the MOIA to future liquefaction damage are under investigation by a local geotechnical engineering firm. An attempt will be made to determine the most cost effective and damage mitigating method. One of the options being investigated involves the construction of stone columns along the length of the runway. This option would require significant closure and reconstruction of the airfield pavements. 


\section{Additional Considerations}

64. Initial estimates by Port of 0akland personnel put the cost for reducing the earthquake susceptibility of the 3,000-ft section of runway affected by the Loma Prieta Earthquake in the vicinity of $\$ 6$ million. Based on this estimate, it would cost approximately $\$ 20$ million to make the entire 10,000-ft runway less susceptible to liquefaction. The immediate question is whether it is worth $\$ 6$ million to make the 3,000-ft end less susceptible when it cost approximately $\$ 3$ million to fix the damage caused by the Loma Prieta Earthquake. (It should be pointed out that the $\$ 3$ million to fix the damage caused by the Loma Prieta Earthquake only included contract construction work; it did not include Port of Oakland personnel time to monitor contracts, to monitor construction, to evaluate the situation, to design the temporary, midterm and long-term fixes, or loss of use damages.)

65. When deciding what action, if any, should be taken to reduce the earthquake susceptibility of the MOIA site, another element to be considered is the Loma Prieta Earthquake itself. The Loma Prieta was of an intensity, duration, and distance from the airfield that only 3,000 ft of runway were damaged. The possibility exists that the next earthquake that would have an affect on the MOIA site would be of larger intensity, duration, and nearness. The primary cause of failure on the runway was liquefaction. The phenomena of liquefaction is dependent on the loading magnitude and duration. A larger event in terms of loading magnitude and duration would be expected to cause a great deal more damage than was experienced as a result of the Loma Prieta Earthquake. Therefore, the entire runway would need to be protected from earthquake damage if any remedial action is to be taken.

66. It should be noted that the Port of Oakland was fortunate to have a pavement construction firm under contract at the time of the earthquake. Considering the amount of damage in the bay area, finding a contractor could have been very difficult. Because of the increased demand for contractors immediately following the earthquake, the cost of hiring a firm not under contract may have been greatly inflated. Since the contractor was on board, his bid prices were used to establish reasonable prices.

67. The Port of Oakland must also consider its users when determining the best approach to reduce the MOIA's vulnerability to earthquake damage. 
The $\$ 3$ million price tag to repair the runway did not take into account any economic loss by the users. If the runway had been completely closed for any length of time, the users may have moved operations to another facility. The users are private firms, and they could move operations to a site that would be less likely to experience substantial damage in the event of another earthquake (although another site may be difficult to find in the bay area).

68. There are many facets that deserve consideration when determining if any remedial action should be taken at MOIA. The first item that needs to be determined is the maximum credible earthquake that could reasonably be expected, i.e. the design earthquake, and the expected response of the site. Once the design earthquake has been determined, the options of trying to prevent damage can be weighed against the consequences of taking no remedial action. Some of the items that need to be considered when evaluating remedial action alternatives include the cost of remedial work, the disruption to users while performing the remedial work, and the benefits to be gained by the remedial action in the event of the design earthquake. Factors that need to be considered for taking no action include the damage that might be expected, the cost of damage repair, and the possible permanent loss of users in the event of the design earthquake. An economic analysis should be performed weighing each of the benefits and liabilities involved with each option. 
69. Pavements are extremely vulnerable to localized earthquake damage because of the distances they must span and the different geological zones and materials on which the pavement structure is founded. Compared to the materials on which they are built, pavements are relatively thin structures. The subgrade materials are an integral, intimate part of the pavement system. A pavement can not be isolated from the supporting subgrade. However, there are things that should be avoided when constructing a pavement to minimize the potential damage that can be caused by an earthquake. When these things cannot be avoided, precautions must be taken to minimize the potential damage that may be caused. Deposits that are particularly vulnerable to earthquake motions such as liquefiable soils should be avoided.

70. The MOIA is located on an extremely vulnerable site, and therefore, precautions in construction should have been taken. The precaution of most benefit would have been to provide greater compactive effort at the time of construction. Since virtually no compactive effort was applied to the hydraulically dredged sand fill, even a minimal compactive effort may have resulted in a much better performance of the MOIA runway damaged by the Loma Prieta Earthquake. Consideration could have also been given to the geology of the area. This may have lead to extending the runway to the east rather than the west (although this may not have been possible for other reasons).

The action of the Loma Prieta Earthquake may have made the MOIA site somewhat less vulnerable to the next earthquake because of the resulting densification of the deposit. The most important lesson learned is that it is much better to take precautions at the time of original construction than to attempt remediation. Any retrofit that may be designed for the MOIA airfield will be costly and difficult to put into place. For any major airfield that is to be constructed in an earthquake zone, an exhaustive investigation into the subsurface zone should be conducted to determine the site's susceptibility to earthquake loadings. The design of airfields in earthquake zones should take into consideration methods for reducing the susceptibility of the site to earthquake damage at the time of initial construction. 


\section{REFERENCES}

Bartlett, S. F., and Youd, L. T. 1990 (Feb). "State-of-the-Art for Assessing Earthquake Hazards in the United States, Report 27, Evaluation of Ground Failure Displacements Associated with Soil Liquefaction: Compilation of Case Histories," Miscellaneous Paper S-73-1, US Army Engineer Waterways Experiment Station, Vicksburg, MS .

Bhandari, R. K. M. 1981. "Dynamic Consolidation of Liquefiable Sands," International Conference on Recent Advances in Geotechnical Earthquake Engineering and Soil Dynamics, St. Louis, Mo.

Ledbetter, R. H. 1985 (Aug). "Improvement of Liquefiable Foundation Conditions Beneath Existing Structures," Technical Report REMR-GT-2, US Army Engineer Waterways Experiment Station, Vicksburg, MS.

Rogers, J. D. 1990 (Oct). "Site Response Variances During Loma Prieta Earthquake, Oakland International Airport, Port of Oakland, California," Letter Report, Rogers/Pacific, Oakland, CA.

Seed, H. B. 1979 (Feb). "Soil Liquefaction and Cyclic Mobility Evaluation for Level Ground During Earthquakes," Journal of the Geotechnical Engineering Division, Vol. 105 No. GT2, Proceedings of the American Society of Civil Engineers, New York, NY.

Seed, R. B. 1990 (Apr). "Preliminary Report on the Principal Geotechnical Aspects of the October 17, 1989 Loma Prieta Earthquake, "University of California at Berkeley, Report No. UCB/EERC-90/05, Berkeley, CA.

Vallerga, B. A. 1986 (Jan). "Pavement Overlay Design Study Jet Runway 11-29, South Field, Metropolitan Oakland International Airport," Oakland, CA. 


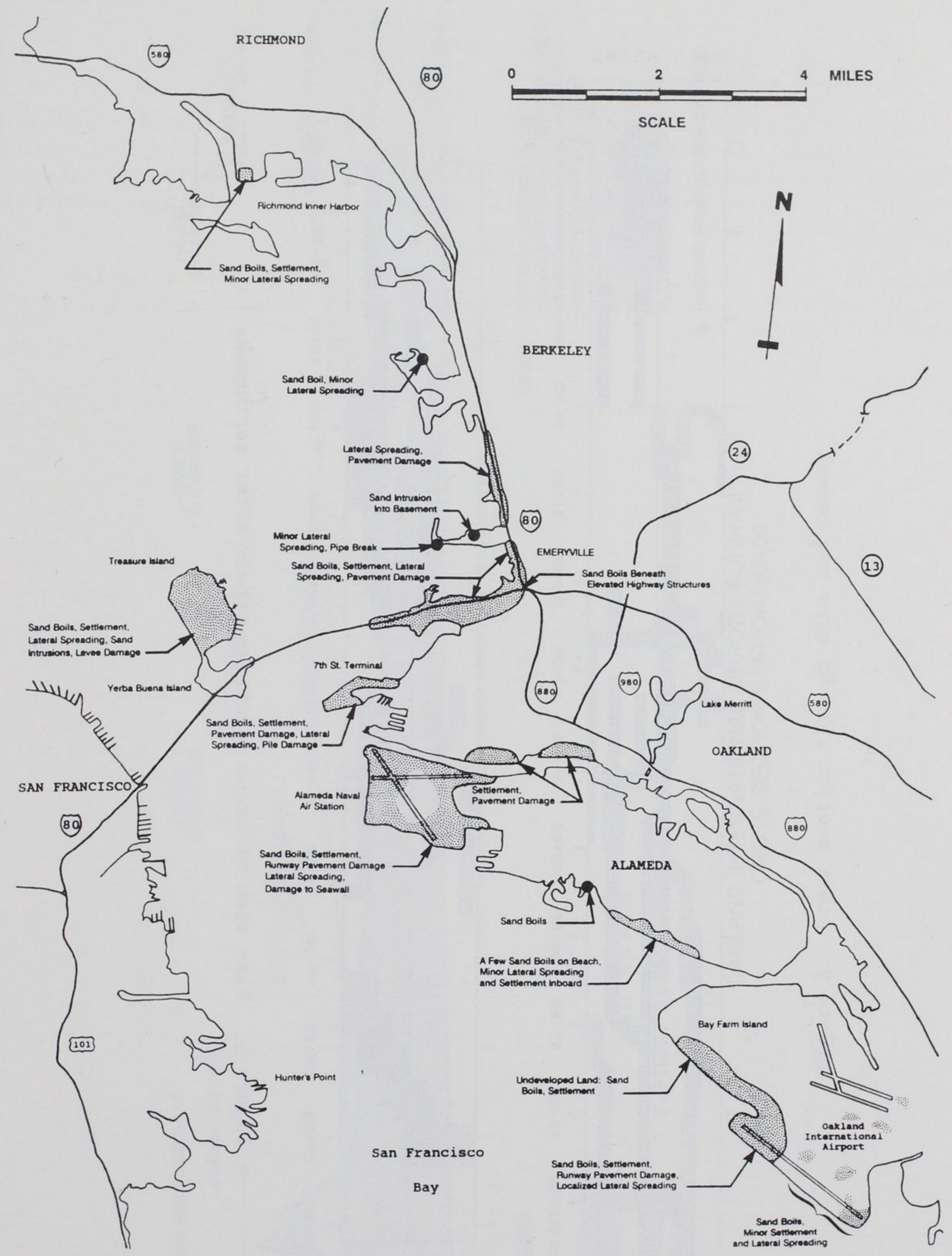

Map of the East San Francisco Bay Shore Region Showing Sites Which Experienced Liquefaction During the Loma Prieta Earthquake of October 17, 1989

Figure 1. East bay areas suffering damage because of liquefaction 

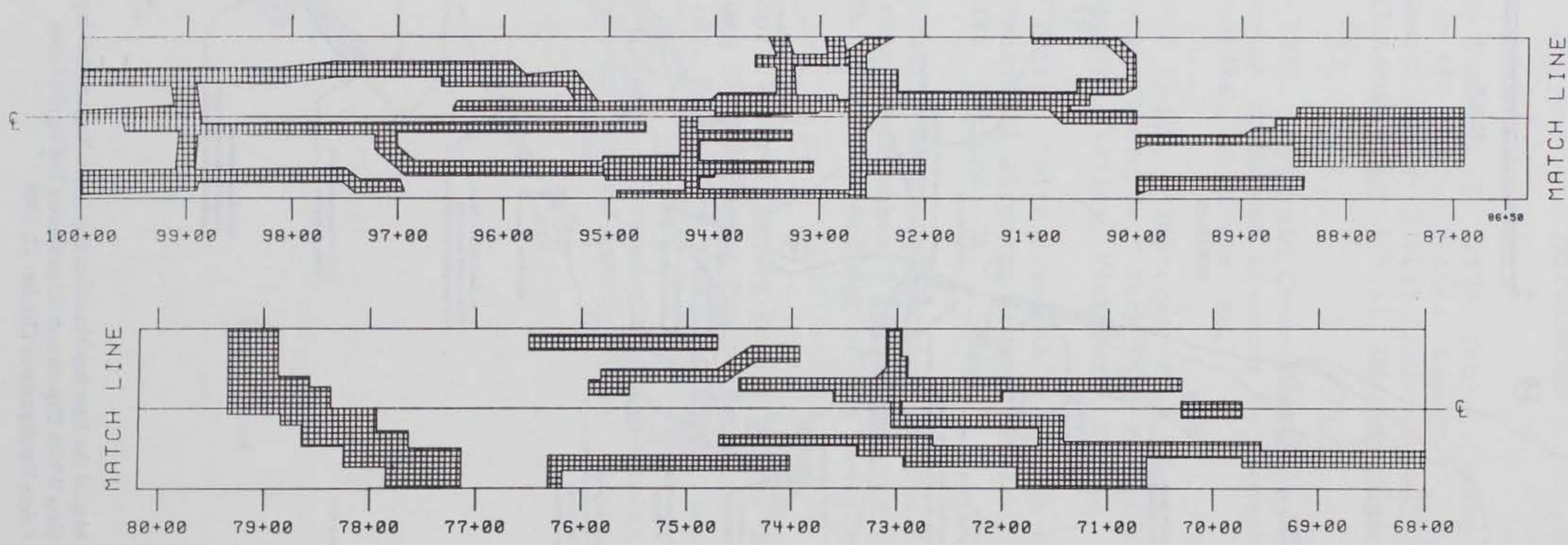

Figure 2. Plan view of areas requiring repair after earthquake 


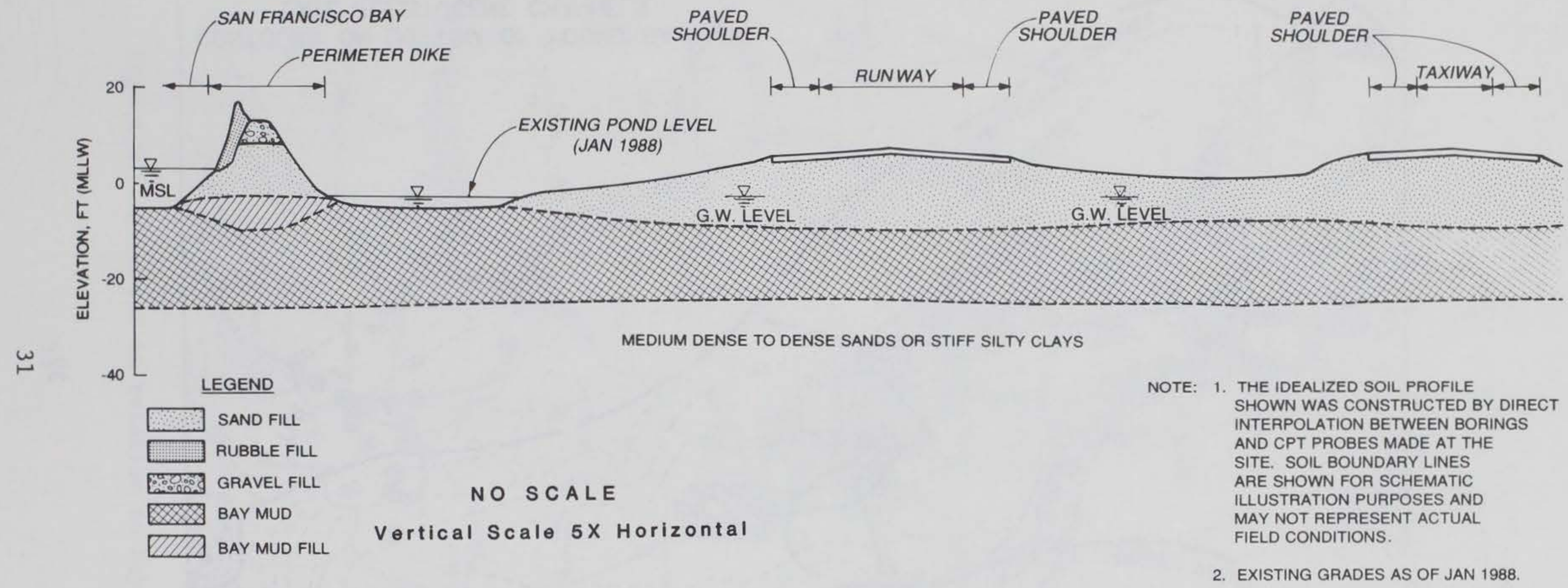

OAKLAND INTERNATIONAL AIRPORT RUNWAY 11-29 CROSS-SECTION STATION $88+00$

Figure 3. Cross section through dike and runway 


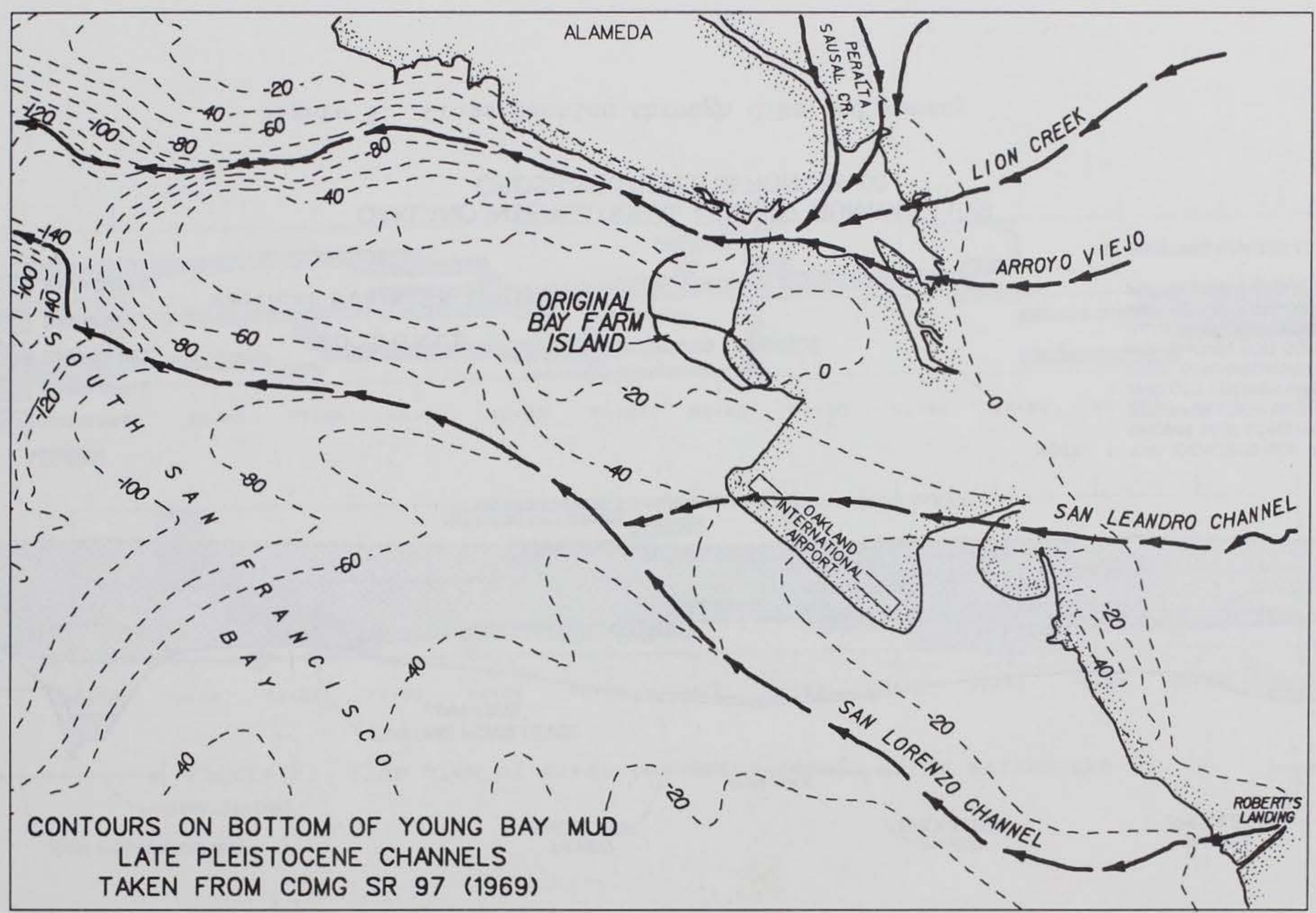

Figure 4. Topography of Young Bay Muds 


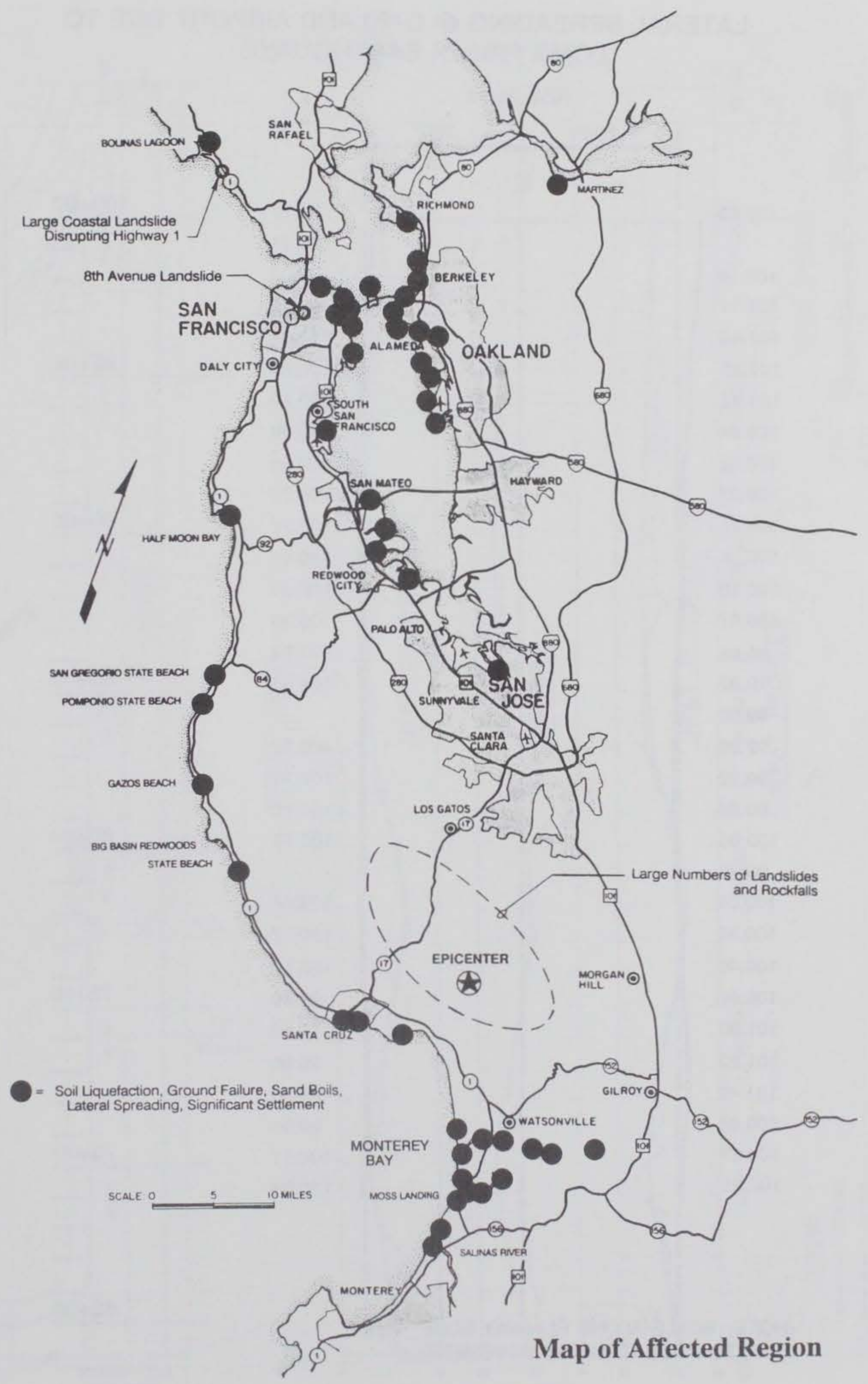

Figure 5. Epicenter in relation to bay area 

LOMA PRIETA EARTHQUAKE

R/W 29-11

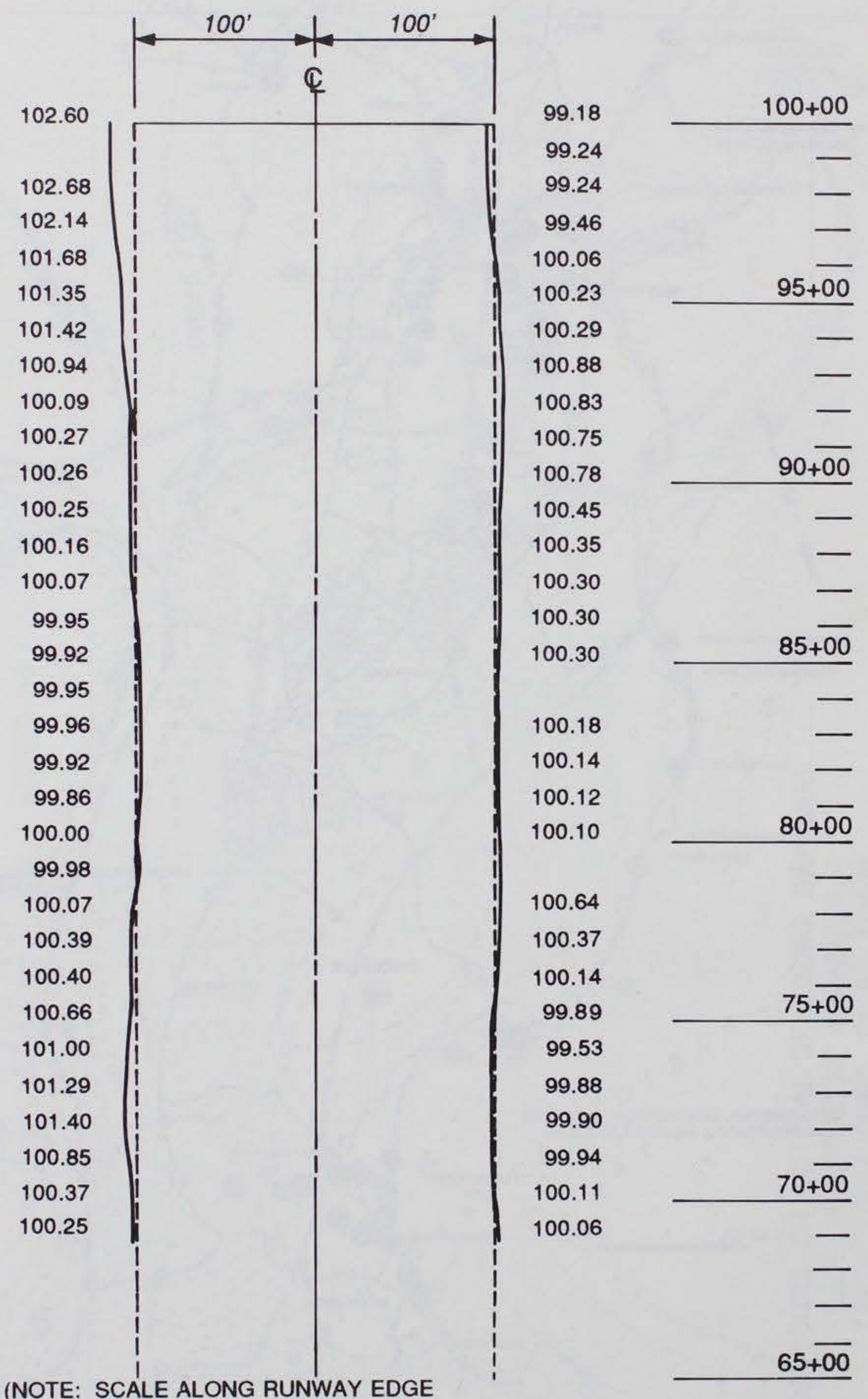
EXAGGERATED TO SHOW MOVEMENT)

Figure 6. Lateral spreading of runway 

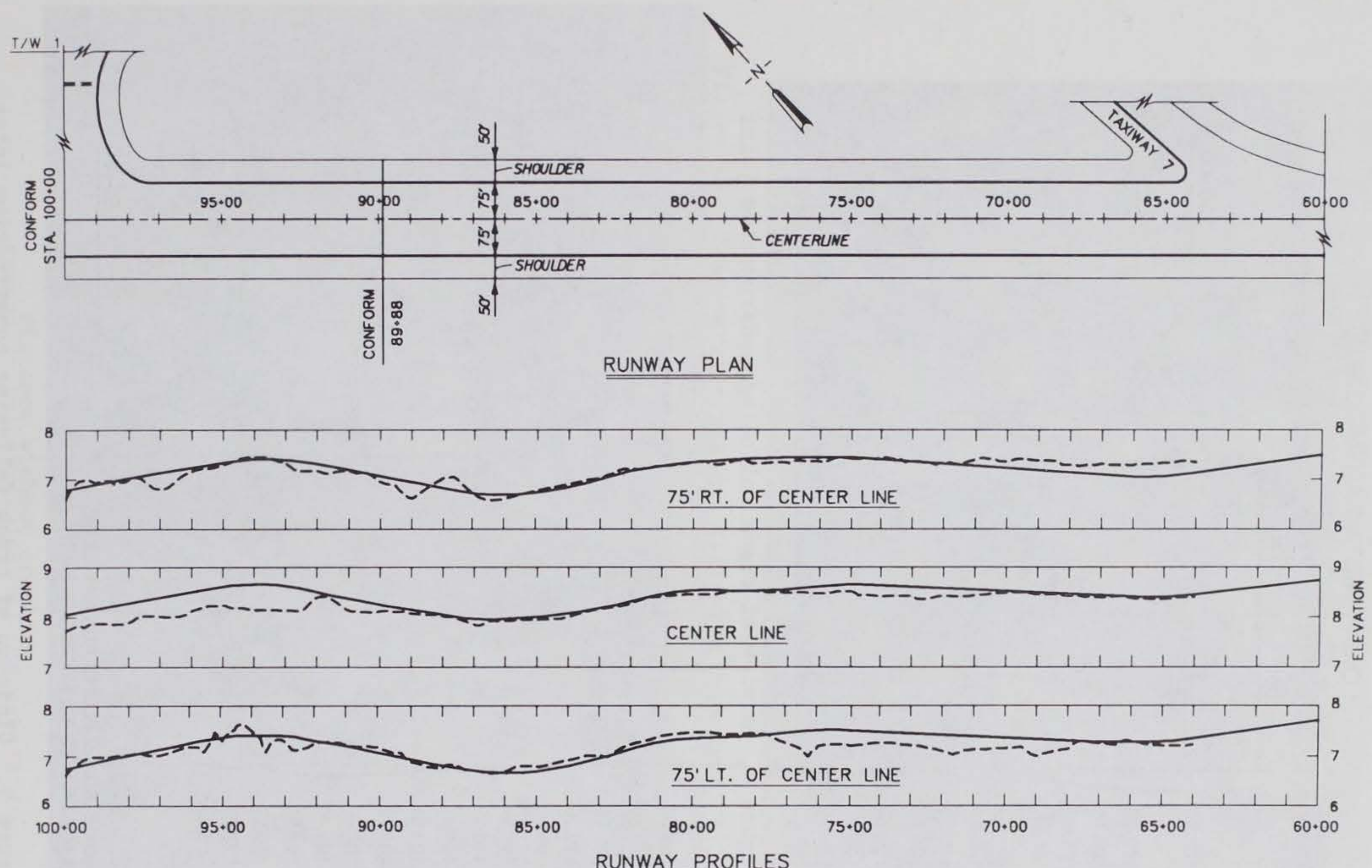

RUNWAY PROFILES

\begin{tabular}{ll}
\multicolumn{2}{l}{ LEGEND } \\
---- & BEFORE \\
--- & AFTER
\end{tabular}

SCALE IN FEET

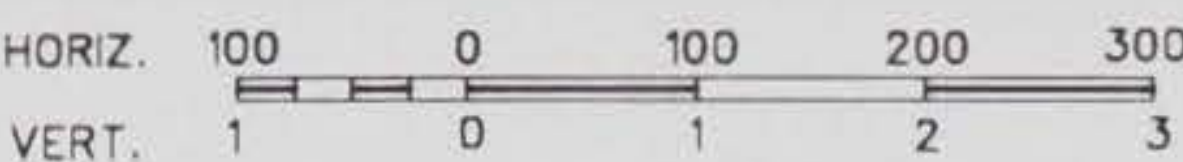




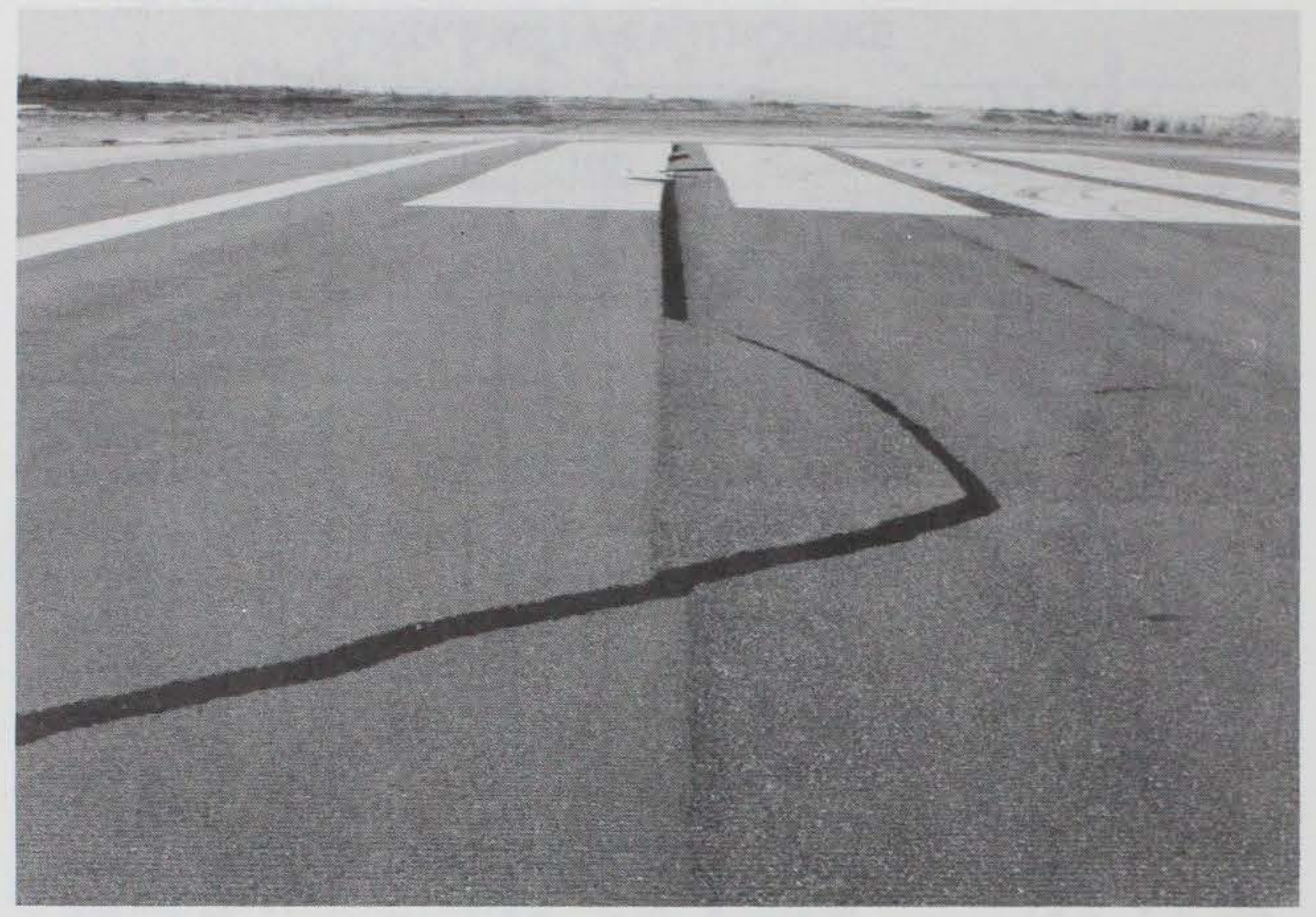

Figure 8. A view of crack following construction joint

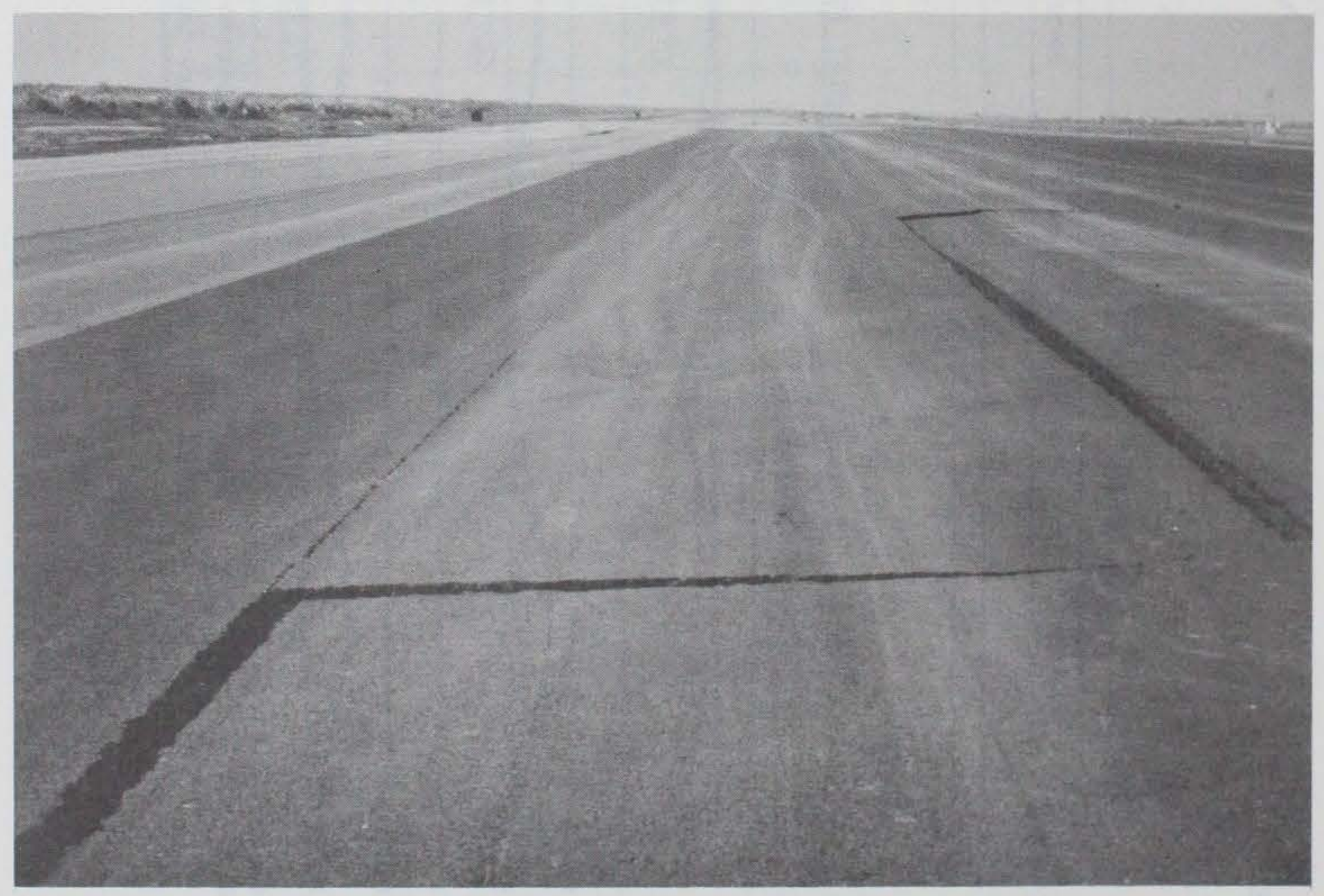

Figure 9. Close-up of crack following construction joint 


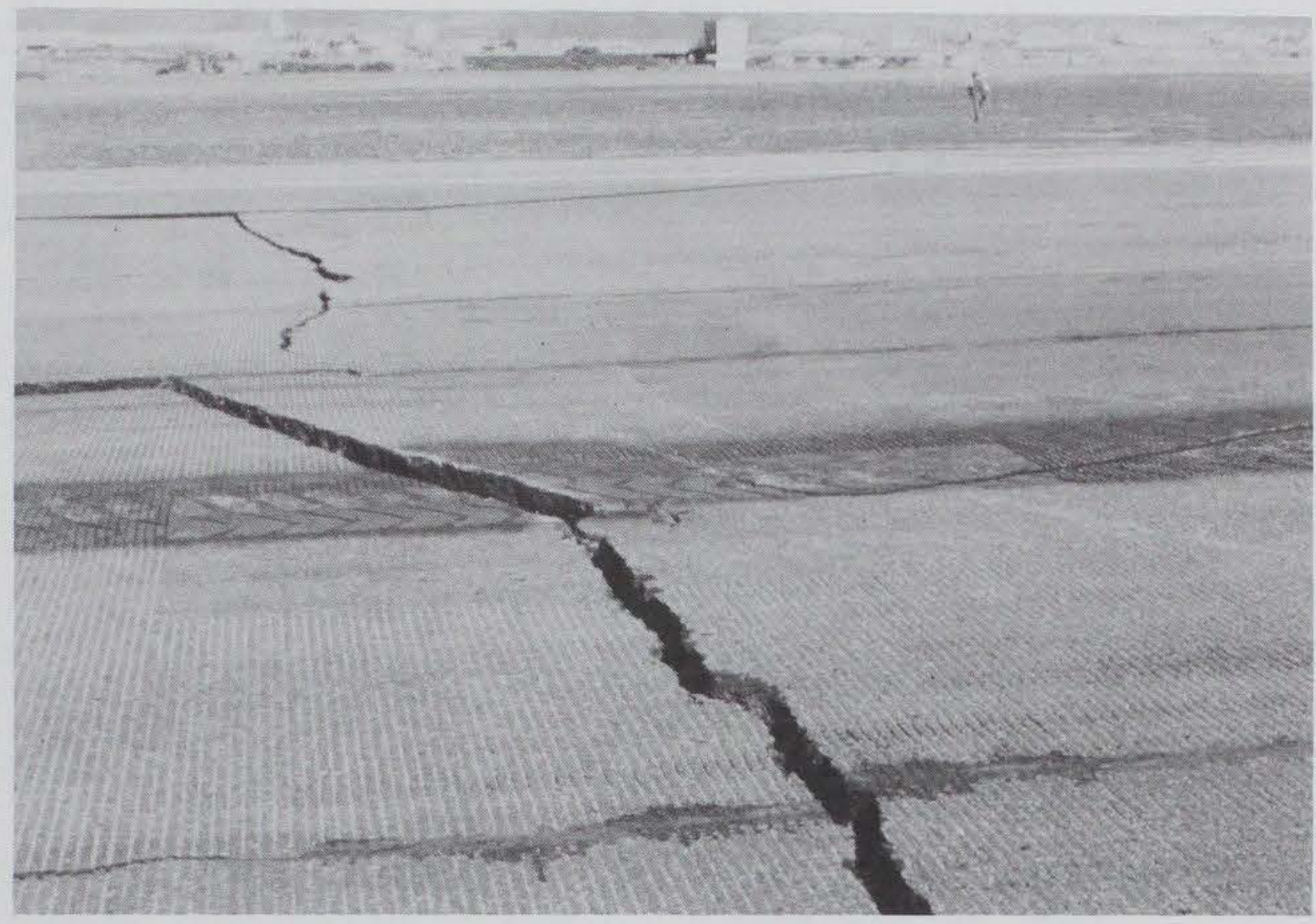

Figure 10. Transverse crack not following construction joint

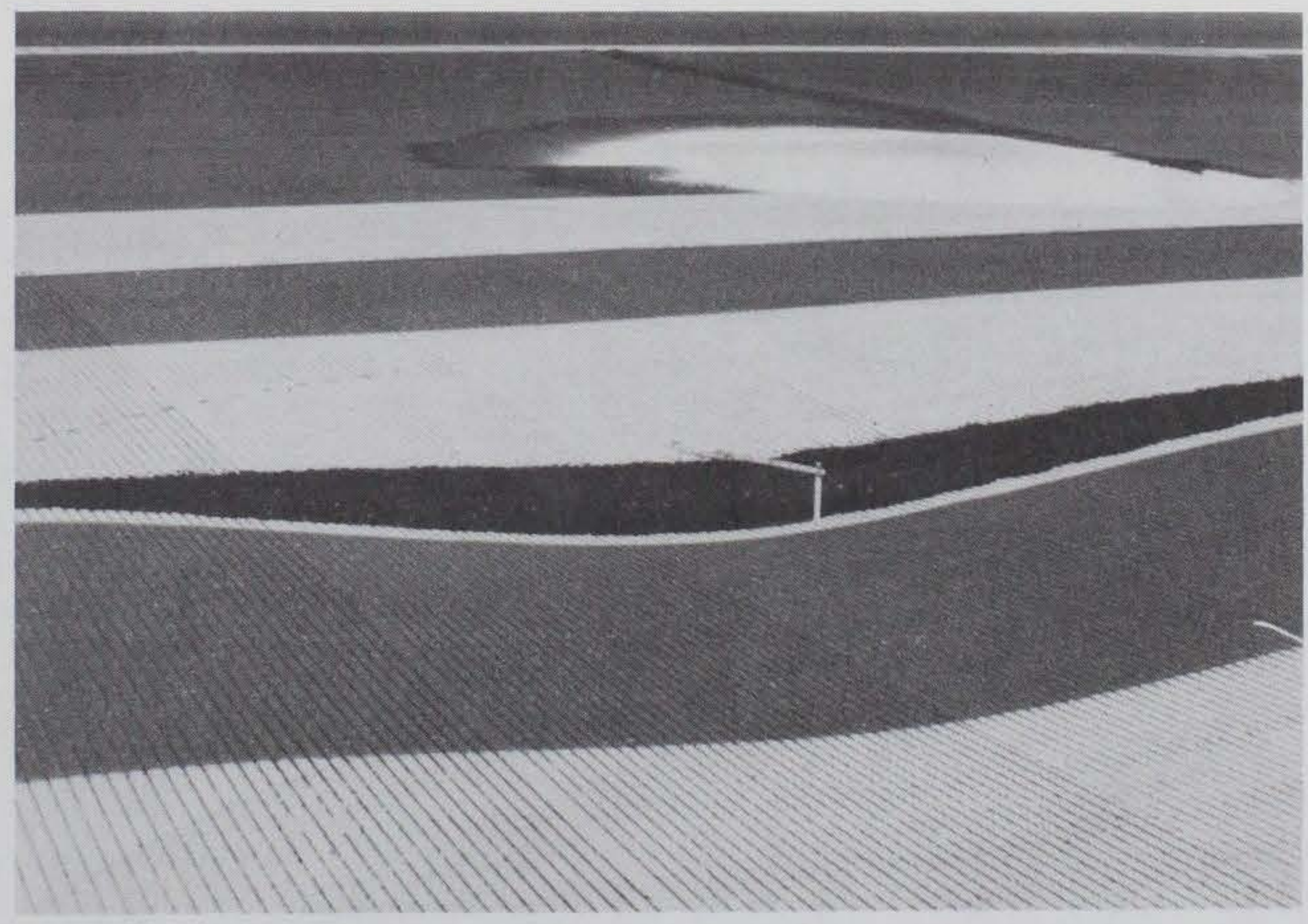

Figure 11. An 8-in. deformation in AC pavement over 11.2 -ft distance without cracking 


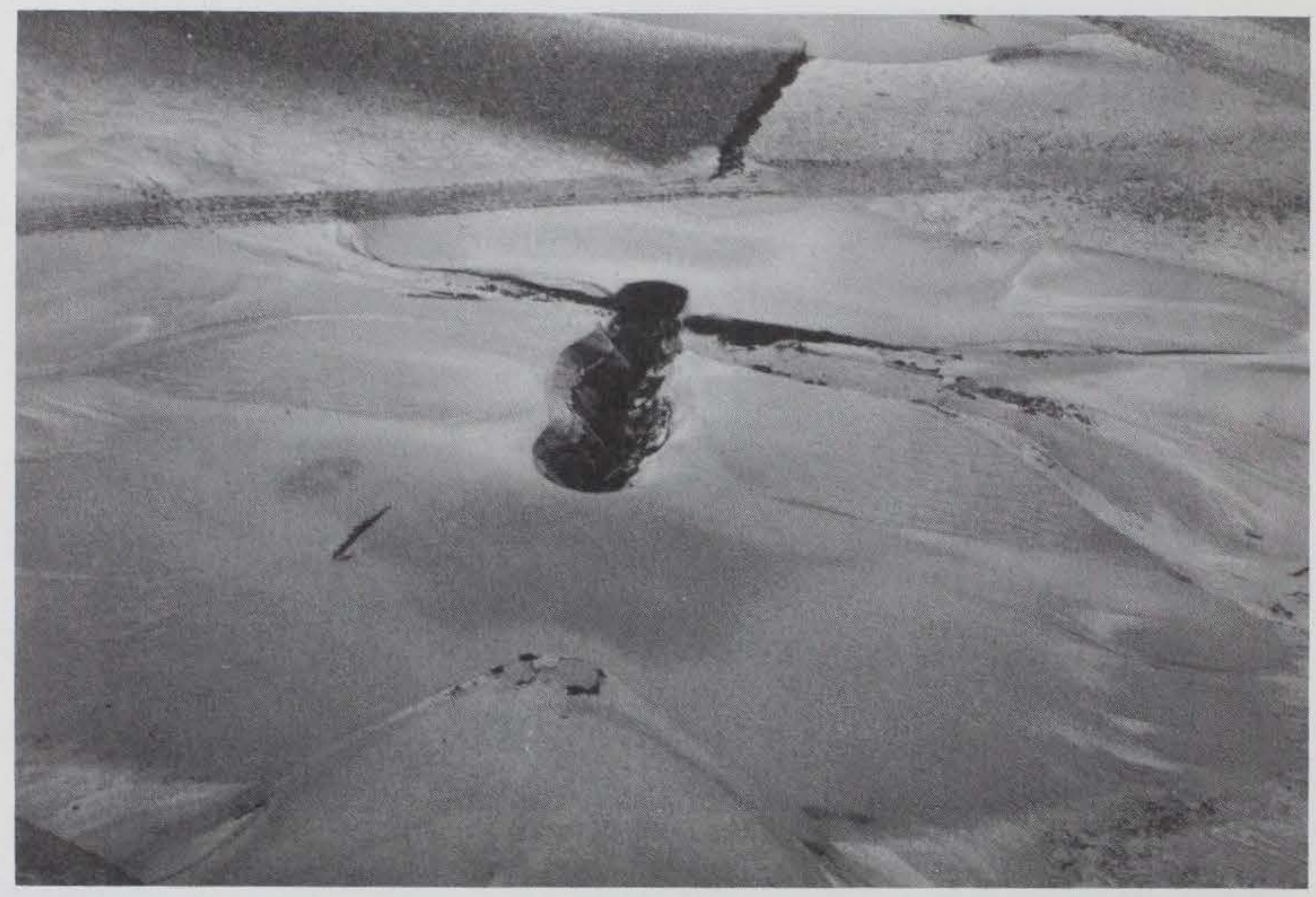

Figure 12. Close-up of sand boil on Runway 11-29

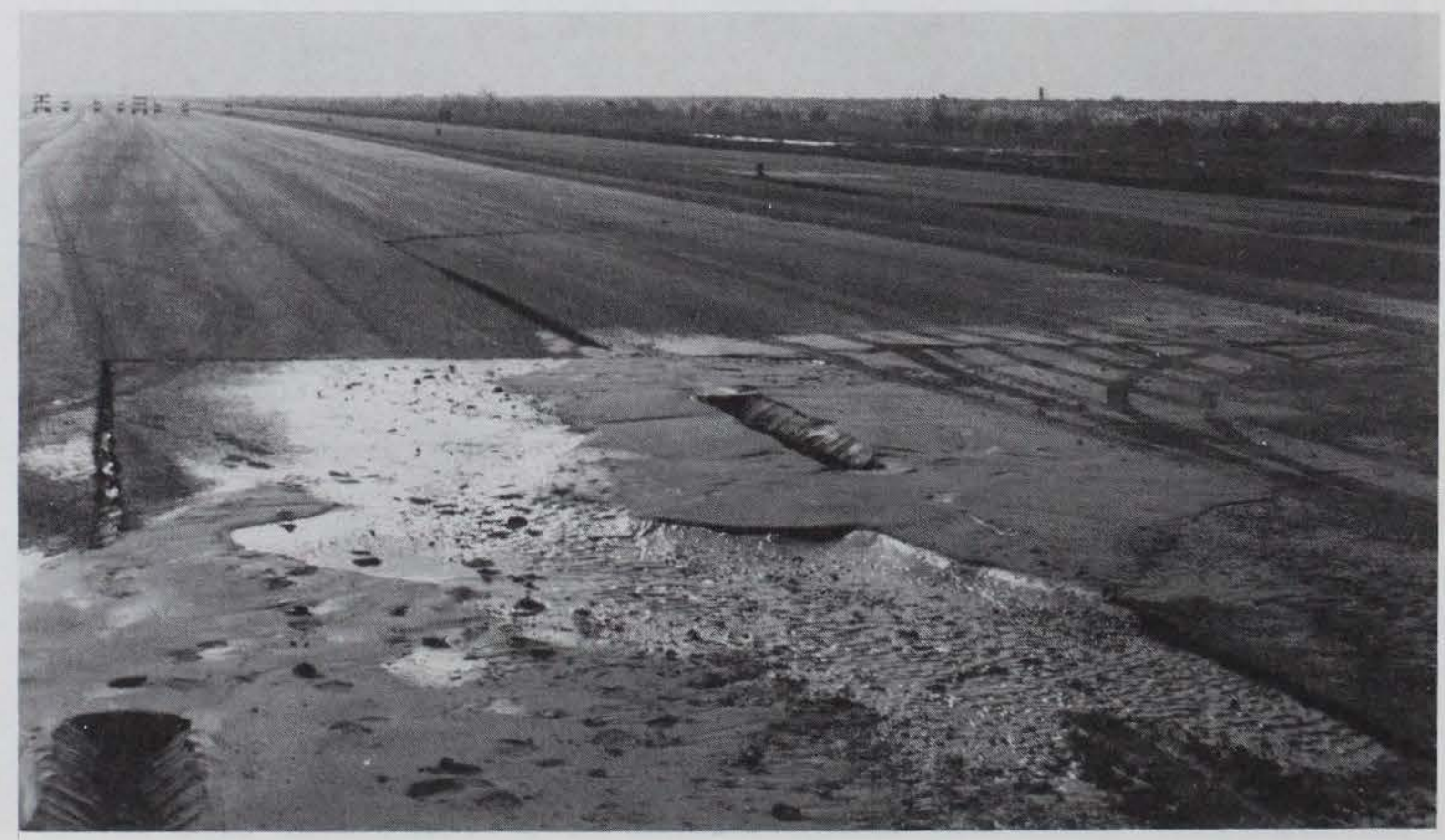

Figure 13. Overall view of sand boil on Runway 11-29 


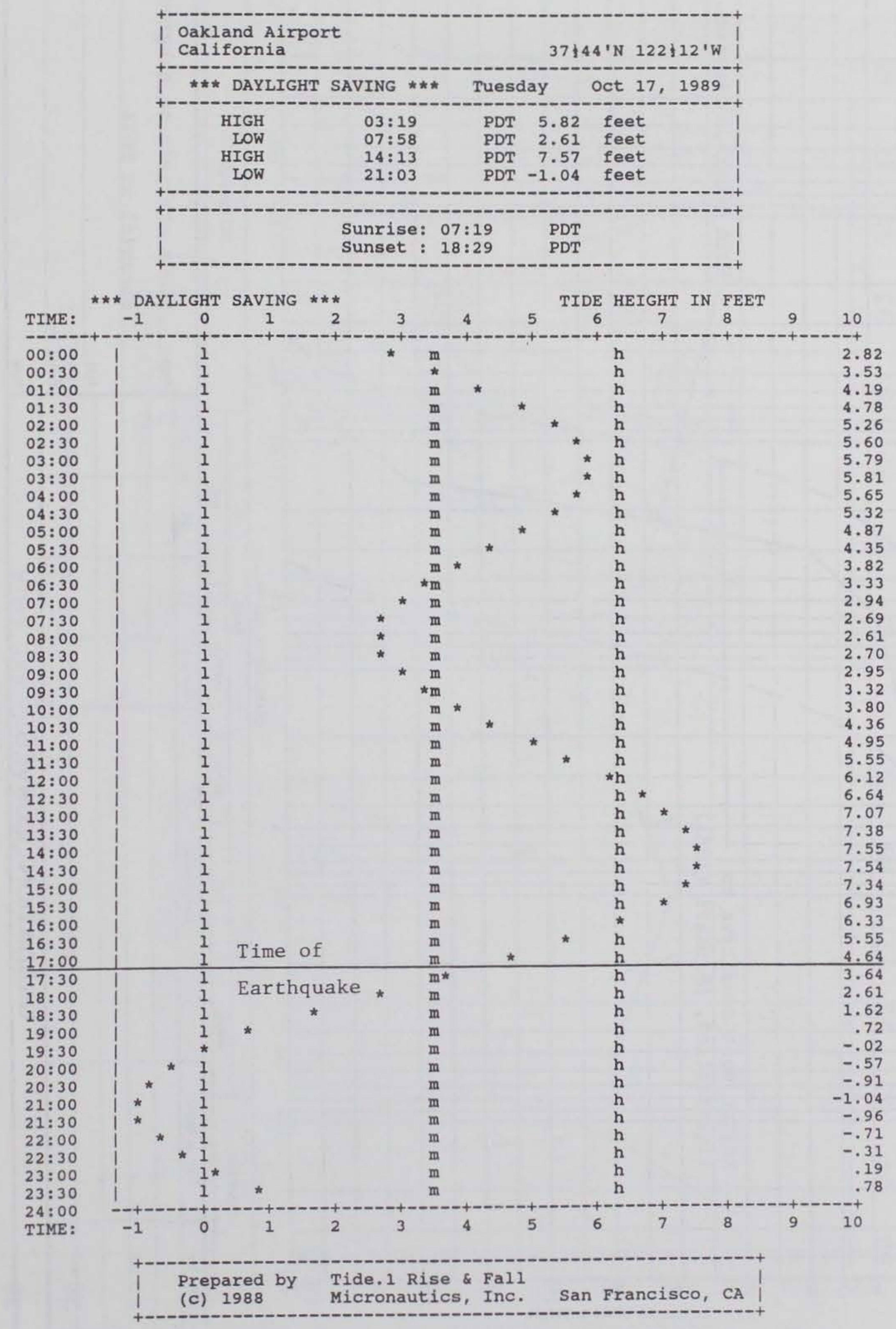

Figure 14. Tide data for 17 October 1987 


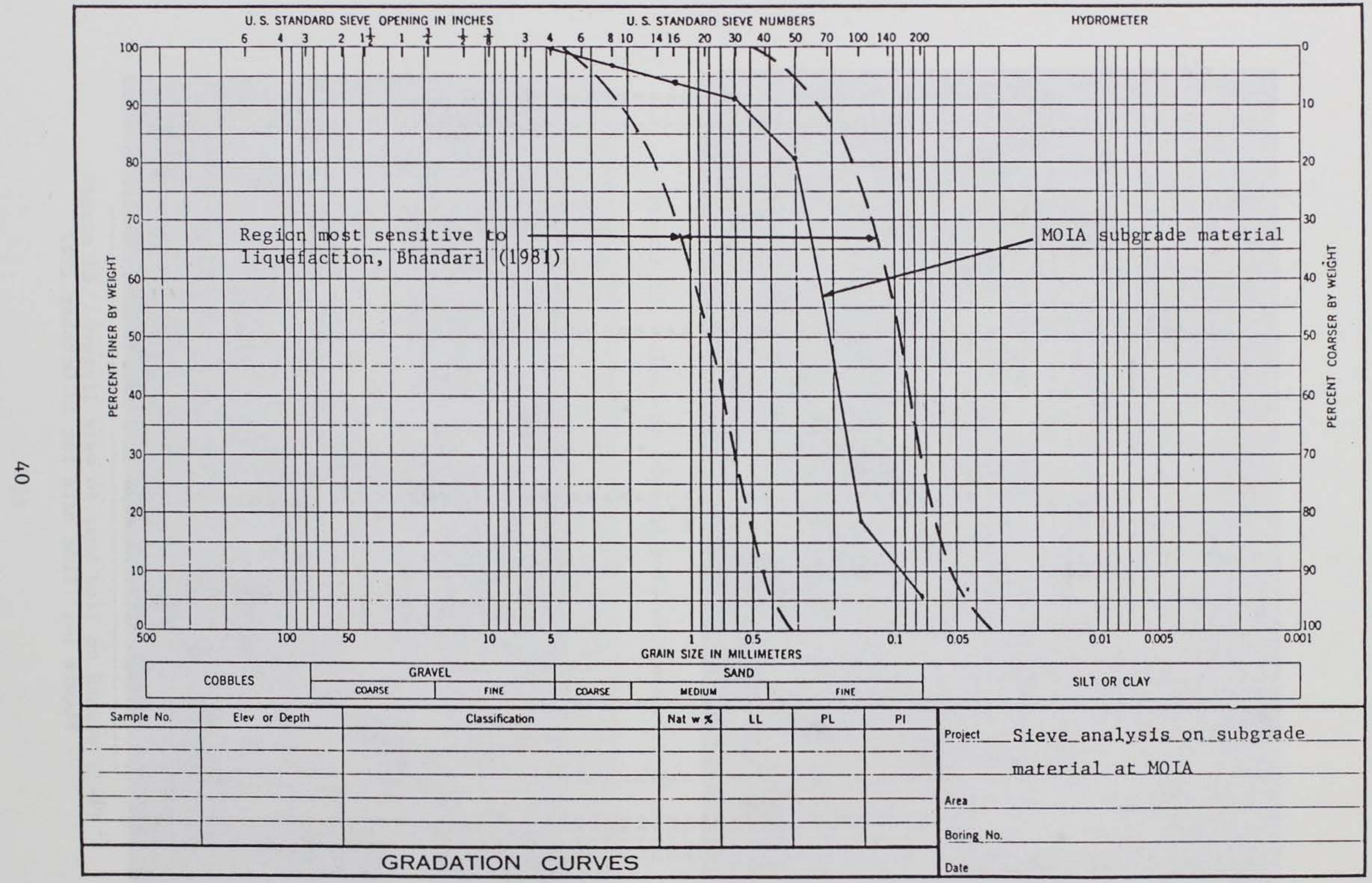

ENG , FORM 2087

Figure 15. Sieve analysis results on sandfill 


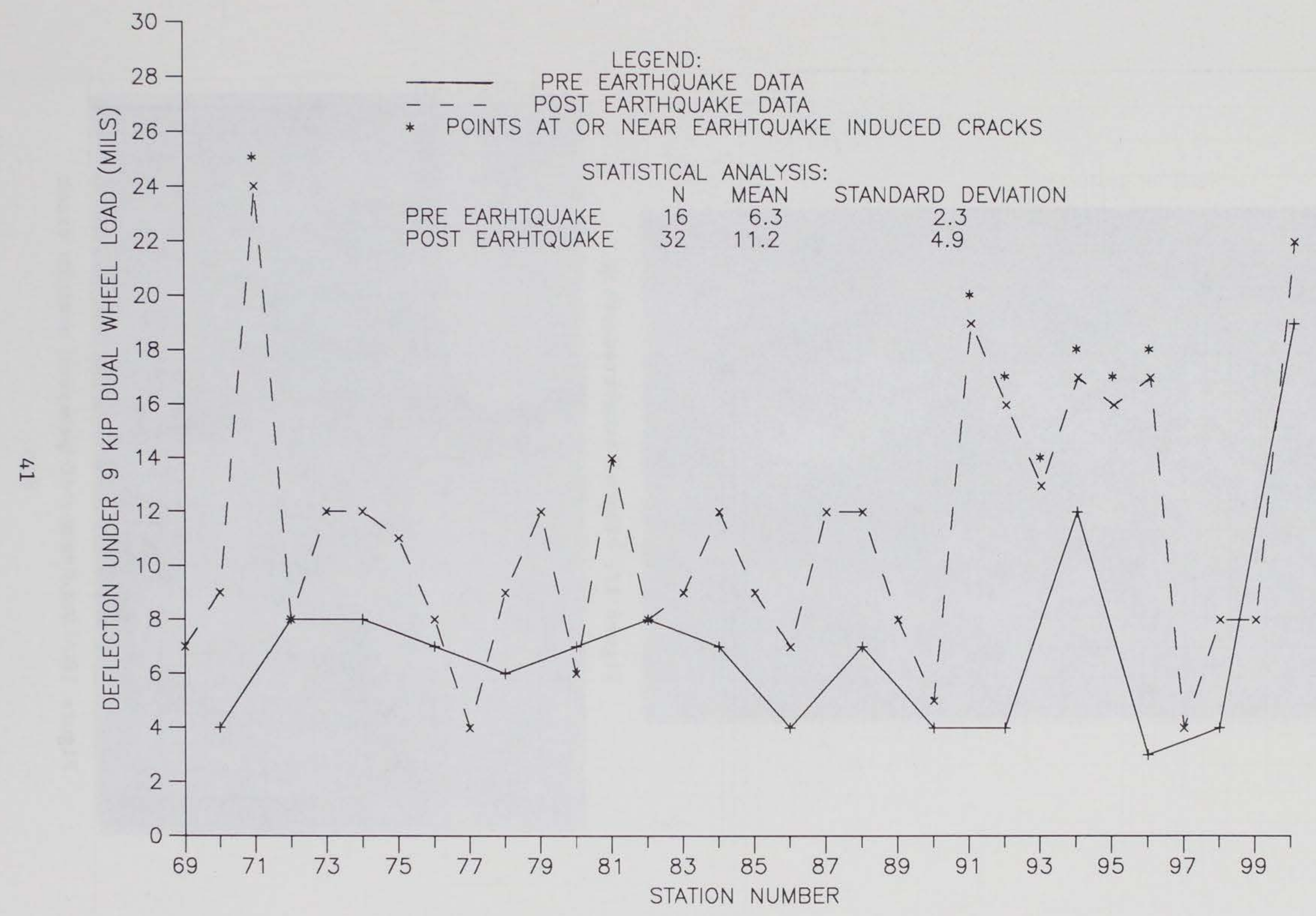

Figure 16. Benkelman beam deflection data 


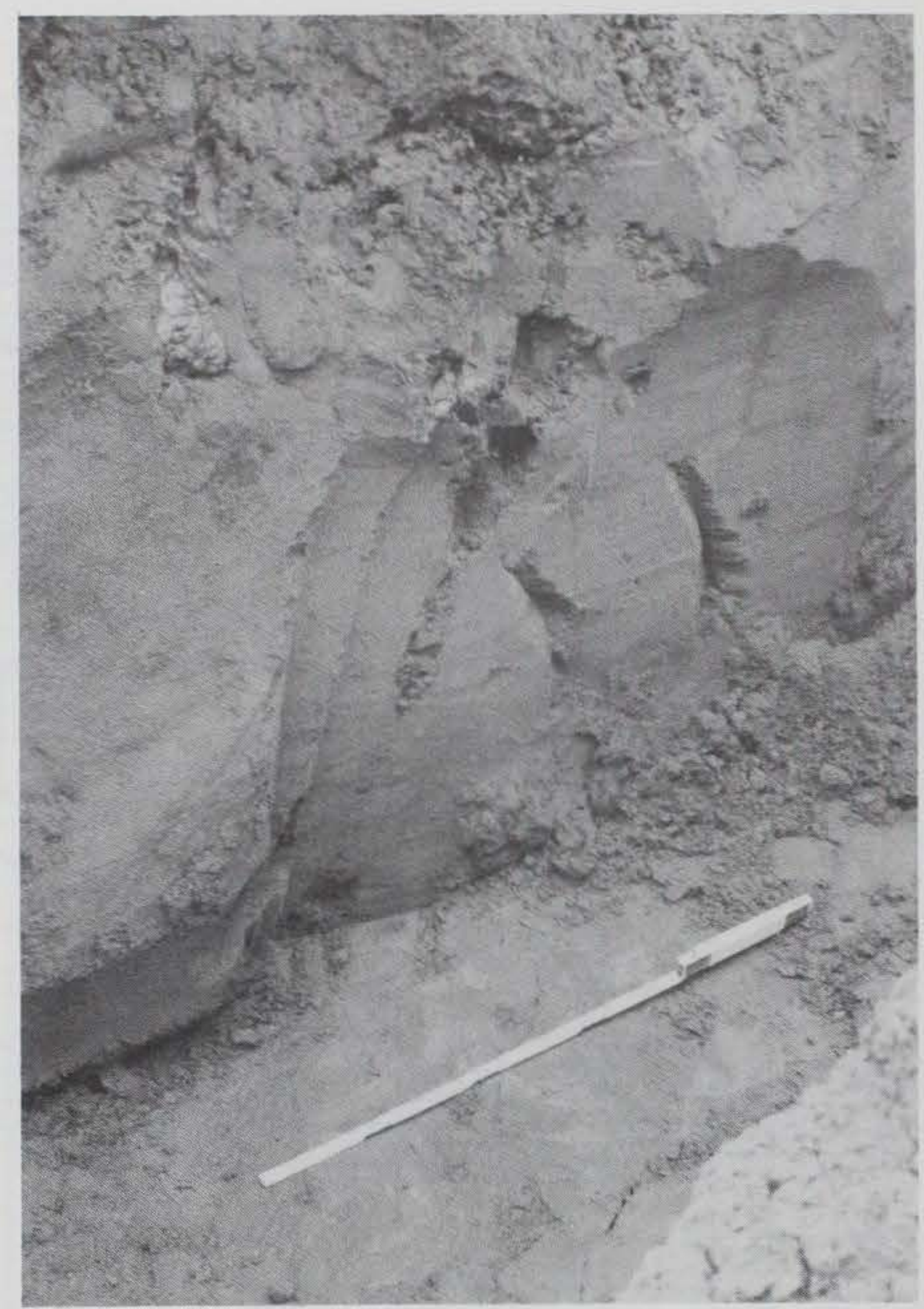

Figure 17. Top of excavated crack

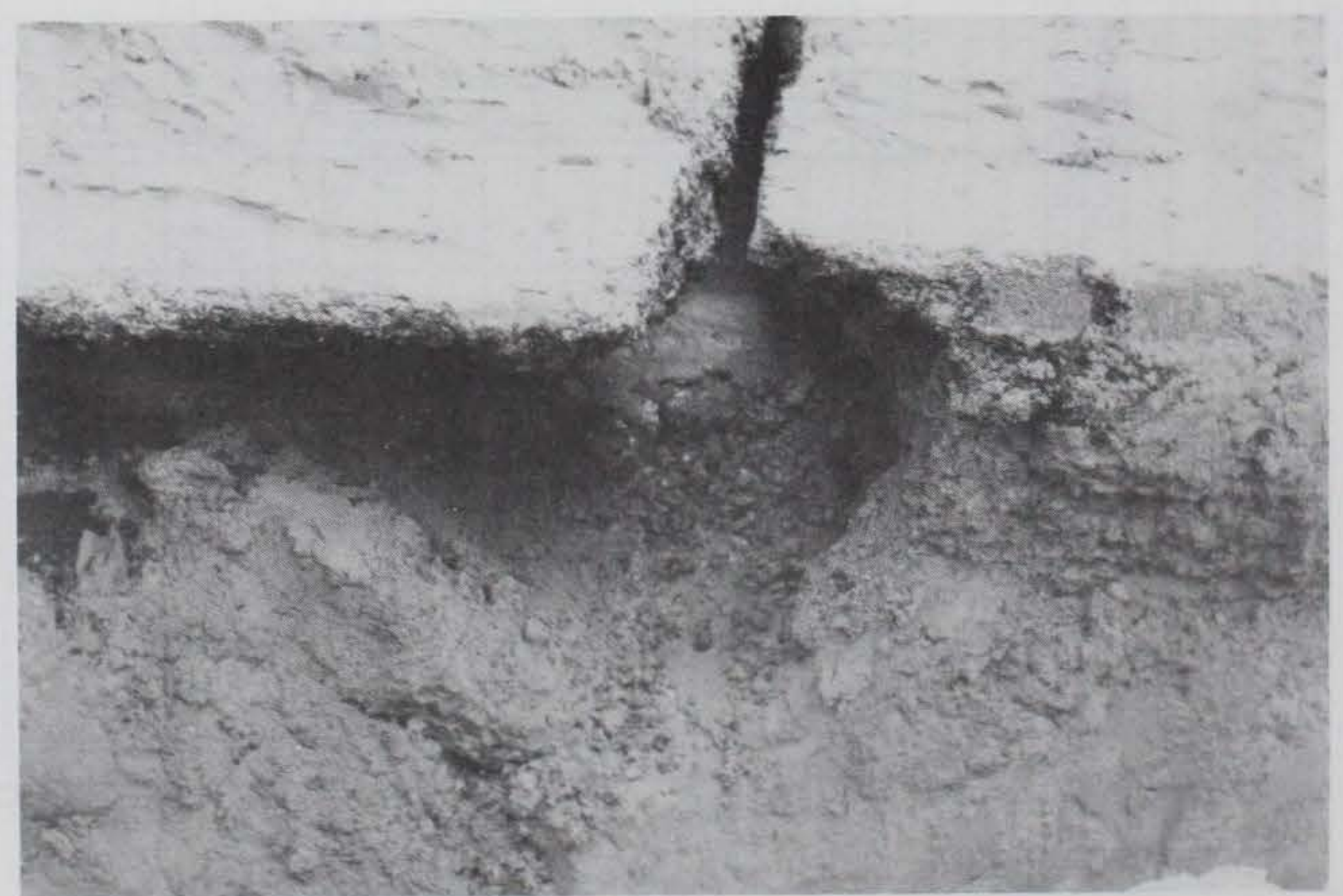

Figure 18. Void under AC pavement next to crack 


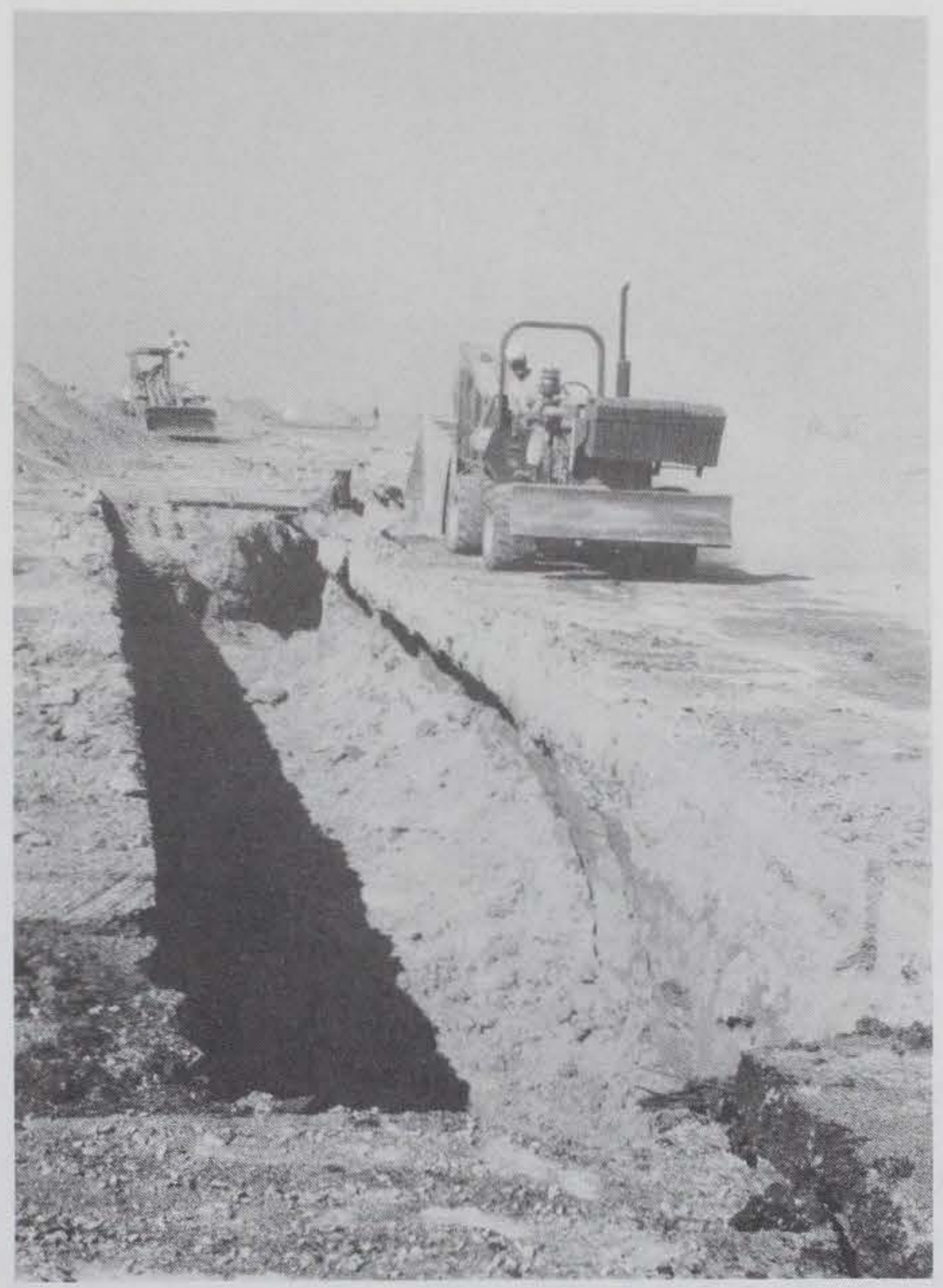

Figure 19. Excavated crack

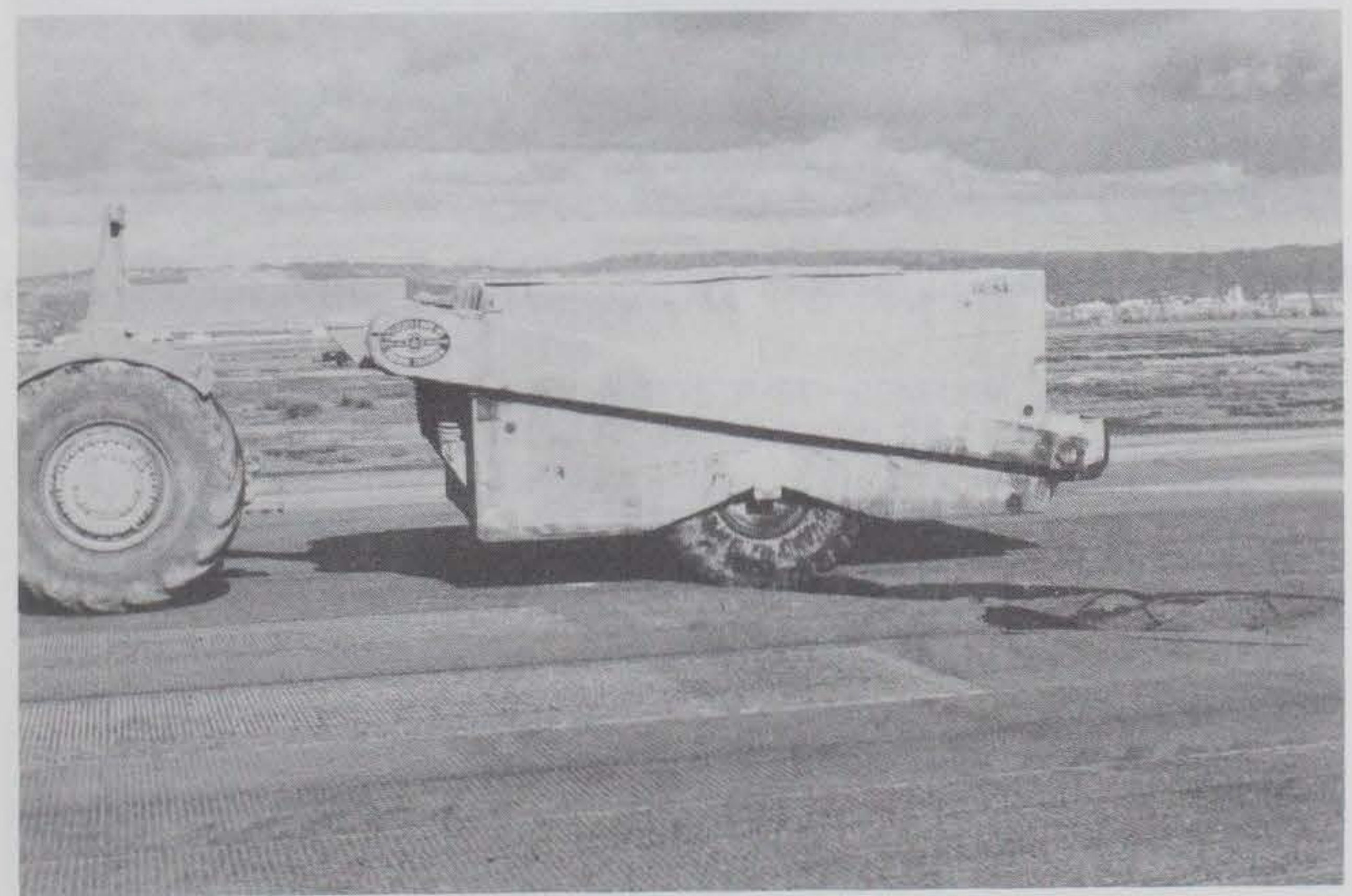

Figure 20. A 50-ton proof roller 


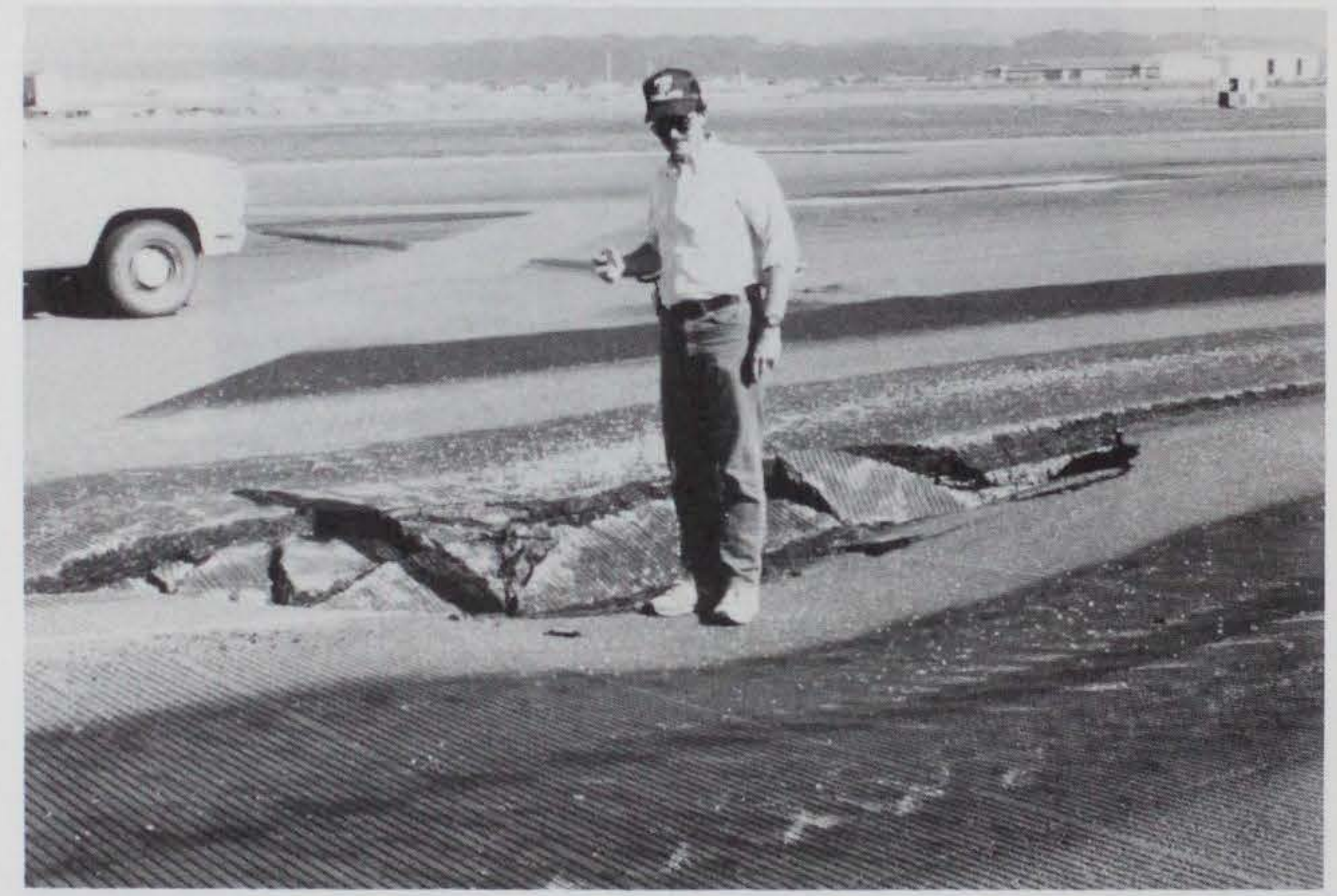

Figure 21. Pavement broken by proof roller adjacent to crack 


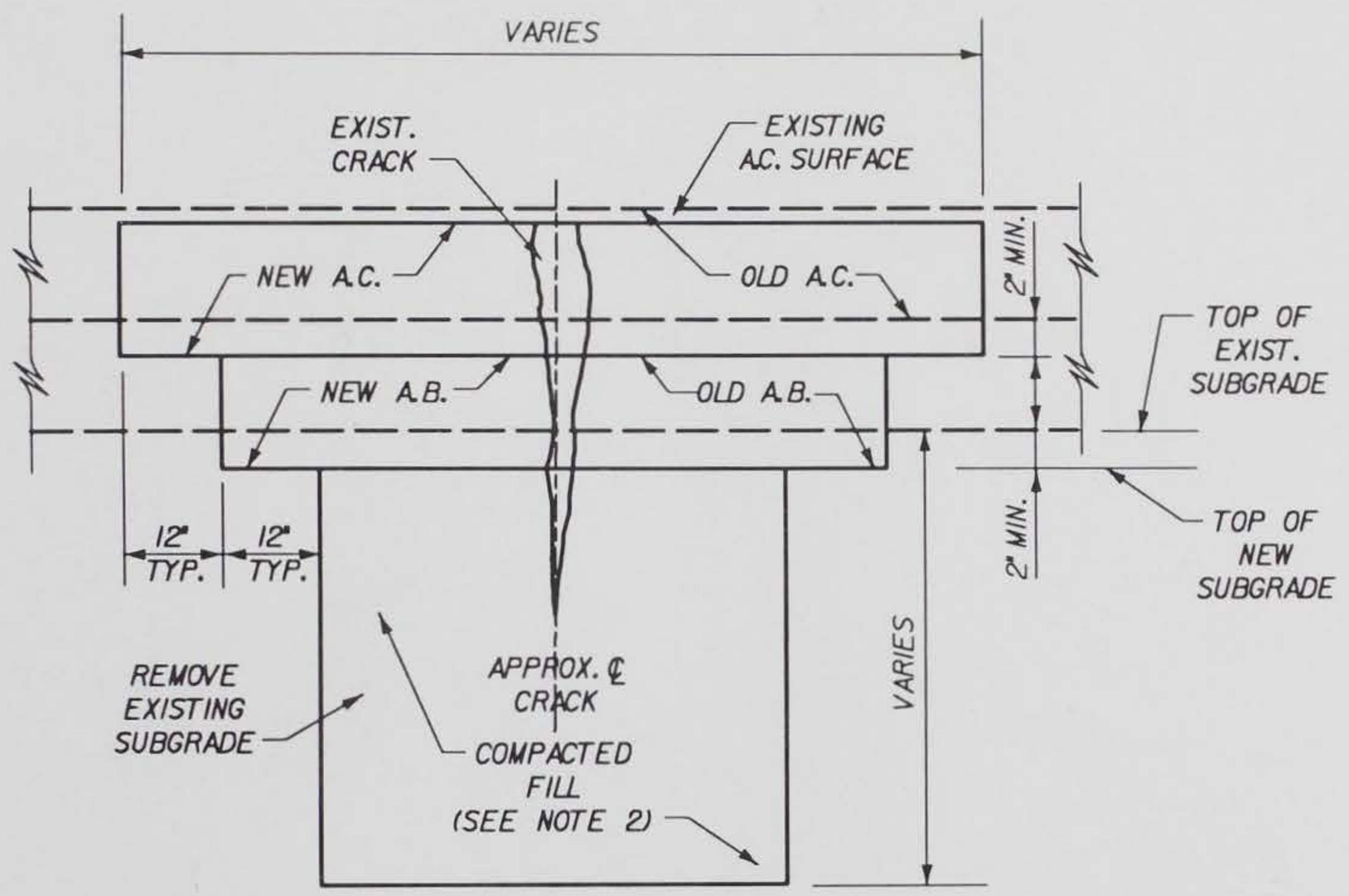

CRACK REPAIR DETAIL

N.T.S.

NOTES: 1. REMOVE AND DISPOSE EXISTING ASPHALT CONCRETE PAVEMENT AND AGGREGATE BASE AS SHOWN ON PLANS OR AS DIRECTED BY ENGINEER.

2. REMOVE EXISTING SUBGRADE MATERIAL AS SHOWN ON THE DETAL. BACKFILL WITH THE SAME MATERIAL AND COMPACT. CONFORM TO CALTRANS SPECIFICATIONS.

3. PLACE AND COMPACT AGGREGATE BASE. CONFORM TO CALTRANS SPECIFICATIONS, CLASS 2, 3/4" MAX. SECTION 26.

4. PLACE AND COMPACT ASPHALT CONCRETE IN ACCORDANCE WITH SPECIFICATIONS FOR CONSTRUCTION OF ASPHALT CONCRETE OVERLAY AND MODIFICATION OF APPROACH LIGHTING SYSTEMS, RUNWAY 11-29.

Figure 22. Crack repair detail 